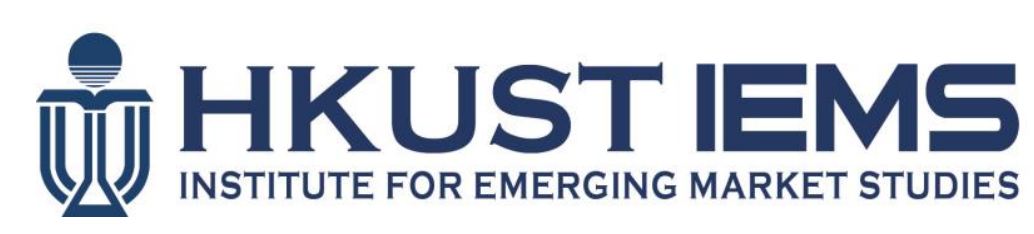

\title{
The Value of Political Ties versus Market Credibility: Evidence from Corporate Scandals in China
}

\author{
Mingyi HUNG, T.J. WONG, Fang ZHANG
}

HKUST IEMS Working Paper No. 2015-18

March 2015

HKUST IEMS working papers are distributed for discussion and comment purposes. The views expressed in these papers are those of the authors and do not necessarily represent the views of HKUST IEMS.

More HKUST IEMS working papers are available at: http://iems.ust.hk/WP 


\title{
The Value of Political Ties versus Market Credibility: Evidence from Corporate Scandals in China
}

\author{
Mingyi HUNG, T.J. WONG, Fang ZHANG
}

HKUST IEMS Working Paper No. 2015-18

March 2015

\begin{abstract}
This paper compares the value of political ties and market credibility in China by examining the consequence of corporate scandals. We categorize Chinese corporate scandals by whether the scandal is primarily associated with the destruction of i) the firm's political networks (political scandals), ii) the firm's market credibility (market scandals), or iii) both (mixed scandals). Consistent with our hypothesis that scandals signaling the destruction of political ties are associated with greater losses in firm value than scandals signaling the destruction of market credibility, we find that the stock market reacts more negatively to political and mixed scandals than to market scandals. In addition, the greater negative market reactions associated with political and mixed scandals are primarily driven by firms that rely more on political networks. We also find that, compared to market scandals, political and mixed scandals lead to larger decreases in operating performance, greater reduction in loans from state-owned banks, and higher departure of political directors.
\end{abstract}

\section{Author's contact information}

Mingyi Hung

Department of Accounting

The Hong Kong University of Science and Technology

Hong Kong

E: acmy@ust.hk

Tel: +852 23587577

T.J. Wong

The Chinese University of Hong Kong

Fang Zhang

Hong Kong Baptist University 


\section{The Value of Political Ties versus Market Credibility: Evidence from Corporate Scandals in China}

MINGYI HUNG, The Hong Kong University of Science and Technology

T.J. WONG, The Chinese University of Hong Kong

FANG ZHANG, Hong Kong Baptist University

November 2014

* Accepted by Ferdinand Gul. We thank Ferdinand Gul (Editor), two anonymous reviewers, Andreas Charitou, Mark DeFond, Douglas DeJong, Zhaoyang Gu, Luzi Hail, Clive Lennox, Pierre Liang, Hai Lu, Joseph Piotroski, Shivaram Rajgopal, Karthik Ramanna, Eddie Riedl, Suraj Srinivasan, Gwen Yu, Tianyu Zhang, Jerald Zimmerman, and workshop participants at Carnegie Mellon University, the Chinese University of Hong Kong, the $35^{\text {th }}$ Annual Congress of European Accounting Association, the 2012 Chinese University inaugural conference on China institutions, governance and accounting, the 2012 Harvard Business School IMO conference, the Hong Kong University of Science and Technology IEMS seminar, and Nanyang Technology University for their helpful comments. We thank Peng Zhang for sharing his data of accounting scandals. The work described in this paper was fully supported by Grant No. CUHK453209 from the Research Grants Council of the Hong Kong Special Administrative Region, China. 


\title{
The Value of Political Ties versus Market Credibility: Evidence from Corporate Scandals in China
}

\begin{abstract}
This paper compares the value of political ties and market credibility in China by examining the consequence of corporate scandals. We categorize Chinese corporate scandals by whether the scandal is primarily associated with the destruction of i) the firm's political networks (political scandals), ii) the firm's market credibility (market scandals), or iii) both (mixed scandals). Consistent with our hypothesis that scandals signaling the destruction of political ties are associated with greater losses in firm value than scandals signaling the destruction of market credibility, we find that the stock market reacts more negatively to political and mixed scandals than to market scandals. In addition, the greater negative market reactions associated with political and mixed scandals are primarily driven by firms that rely more on political networks. We also find that, compared to market scandals, political and mixed scandals lead to larger decreases in operating performance, greater reduction in loans from state-owned banks, and higher departure of political directors.
\end{abstract}

JEL Classification: G30, K40, M41

Keywords: corporate scandal, political ties, market credibility, China 


\section{The Value of Political Ties versus Market Credibility: Evidence from Corporate Scandals in China}

\section{Introduction}

Political ties and market credibility are valuable to firms (Faccio, Masulis, and McConnell 2006; Karpoff, Lee, and Martin 2008a, b). Prior research finds that loss of political ties or market credibility destroys firm value (Fisman 2001 for political ties, and Palmrose, Richardson, and Scholz 2004 for market credibility). However, these prior studies focus on examining the value of political ties and market credibility separately. We attempt to fill a void in the literature by comparing the value of political ties versus market credibility among firms in emerging economies, where the government exerts significant control of the markets.

We estimate the value of political ties and market credibility using events that signal the destruction of these values (i.e., corporate scandals). In addition, we use evidence from China for three reasons. First, China has prevalent state-connected enterprises and a relatively high frequency of corporate scandals. Second, like other emerging economies, there are competing political and economic forces in China that shape the relative importance of political ties and market credibility. Third, as the world's second largest economy, China provides a rich market depth for our analysis.

The Chinese government has continued to retain substantial control over the corporate sector even after twenty years of state enterprise reform. Political ties enable both state and non-state firms to engage in implicit and explicit contracts with the government and its related entities, ranging from capital financing, operational contracts to direct subsidies. Thus, scandals that signal the destruction of firms' political ties reduce firm value by hurting their future opportunities to contract with the government and losing the rents associated with these contracts. However, the recent development in market infrastructure, legal institutions, and regulations has led to more market-based contracts among Chinese listed firms, thereby making market credibility 
increasingly important. ${ }^{1}$ Because scandals that signal the loss of market credibility reduce firms' ability to contract with market participants and reduce outside shareholders' expectation that the firms will share the payouts associated with these contracts, these scandals also reduce firm value. Following prior studies that suggest that China has more political-based contracts than marketbased contracts (Lin, Cai, and Li 1996; DeFond, Wong, and Li 2000; Fan, Rui, and Zhao 2008; Wang, Wong, and Xia 2008; Hung, Wong, and Zhang 2012), we hypothesize that scandals signaling the loss of political ties have a greater negative effect on firm value than scandals signaling the loss of market credibility. To the extent the recent economic reforms have shifted China from political-based to more market-based contracting, market credibility may be just as important if not more important than political ties. Thus, whether political ties are more valuable than market credibility remains an empirical issue.

We test our hypothesis using a sample of 236 Chinese corporate scandals from 1997 to 2005. As in prior studies (Karpoff et al. 2008a, b), we identify firms engaged in misconduct using regulatory enforcement actions. Specifically, we identify corporate scandals as enforcement actions against firms or their managers by Chinese courts or securities regulators. These enforcement actions include not only financial misrepresentation, but also asset misappropriation and bribery. We classify corporate scandals into three categories: (1) political scandals - scandals that are primarily associated with the destruction of political ties but not market credibility, (2) mixed scandals - scandals that are associated with the destruction of both political ties and market credibility, and (3) market scandals - scandals that are primarily associated with the destruction of market credibility but not political ties.

\footnotetext{
${ }^{1}$ We define market credibility as credibility of a firm's market-based contracting mechanisms such as financial disclosure and protection of minority shareholders against wealth expropriation.
} 
We first identify 31 scandals as political scandals. Examples of political scandals include managers bribing the government or stealing from the state through tax evasion. Next, we identify 107 market scandals. One example of a market scandal is financial misrepresentation, because accounting disclosure is critical for outside stakeholders' decisions in doing business with the firm. Another example is managers misappropriating firm assets, for instance, through embezzlement, kickbacks, or tunneling, because these types of actions effectively involve theft from shareholders. ${ }^{2}$ Finally, we identify 98 mixed scandals. An example of a mixed scandal is embezzlement by managers of state-owned enterprises (SOEs). Embezzlement by managers, that is, the theft of firm assets by managers, creates mistrust among outside shareholders and stakeholders and hence limits the firm's ability to conduct contracting with these market participants. However, because embezzlement by SOE managers implies theft from the government, it also damages the firm's political networks and hence its ability to contract via these relationships.

Consistent with our hypothesis, we find that political scandals and mixed scandals (i.e., scandals signaling the destruction of firms' political ties) are associated with worse stock returns than market scandals (i.e., scandals signaling the destruction of firms' market credibility). We also find results continue to support our hypothesis after further controlling for monetary and nonmonetary legal penalties imposed on firms and individuals. In addition, the greater negative market reactions associated with political and mixed scandals are primarily driven by firms that rely more on political networks. These results suggest that the Chinese economy is more politicalbased than market-based.

\footnotetext{
${ }^{2}$ Alternatively, political scandals can be viewed as 'stealing from the government' and therefore damage the firms' contracting ability with the government, while market scandals can be viewed as 'stealing from the shareholders' and therefore hurting the firms' ability to contract with shareholders.
} 
Additional analyses corroborate our inferences by finding that firms with political and mixed scandals have a larger decrease in operating performance and loans from state-owned banks than firms with market scandals. Firms with political and mixed scandals also experience greater destruction and realignment of their political networks as reflected in the departure and entrance of their political directors. Further, political scandal firms that successfully repair their political networks experience higher post-scandal stock returns.

The paper contributes to the literature in two ways. First, our study is the first to compare the price effects and other economic consequences of scandals that signal the destruction of political ties versus scandals that signal the destruction of market credibility. We add to the corporate scandal literature that primarily focuses on market scandals involving financial misrepresentations (for U.S. markets: Palmrose et al. 2004; Srinivasan 2005; Miller 2006; Karpoff et al. 2008a, b; Kedia and Philippon 2009; Lennox and Pittman 2010; and for non-U.S. markets: Chen, Firth, Gao and Rui 2005; Weber, Willenborg, and Zhang 2008).

Second, our paper complements prior research of political ties. We focus on the net benefits/costs of losing political ties while prior papers study costs (Dinc 2005; Chaney, Faccio, and Parsley 2011) and benefits (Johnson and Mitton 2003; Faccio 2006; Leuz and Oberholzer-Gee 2006). In addition, with the exception of Fisman (2001) that studies the disruption of political ties, ${ }^{3}$ all the other prior studies investigate how the possession of political ties impacts firm value. Contrary to the results in Fan, Wong, and Zhang (2007) that the possession of political ties negatively affects post-IPO stock returns of Chinese firms, we find that the destruction of political ties is associated with a decline rather than rise in firm value. Our finding suggests that while the scandal firms in China likely still bear the costs from excessive government control and

\footnotetext{
${ }^{3}$ We note that Fisman (2001) is a study of political events and political connections, not a study of corporate scandals. Specifically, Fisman (2001) documents a significant price decline of Indonesian firms surrounding the news of President Suharto's worsening health.
} 
intervention, they lose their expected benefits and rents from state loans and other government contracts.

\section{Hypothesis development}

China is commonly perceived as a country with weak legal institutions and strong government control of the corporate sector (La Porta, Lopez-de-Silanes, Shleifer, and Vishny 1998; Allen, Qian, and Qian 2005). Explicit and implicit contracts based on political networks - such as government contracts, state loans, listing rights, equity issuances, government subsidies, operational rights, and other privileges - are widespread (Faccio 2006; Faccio et al. 2006). A substantial portion of listed Chinese firms are SOEs in which the government has influence over the appointment of key executives and external auditors, and the firm's ability to obtain state subsidies, loans and access to the equity markets (DeFond et al. 2000; Fan et al. 2008; Wang et al. 2008; Hung et al. 2012). Even non-state firms need to build connections with the government in order to obtain favors (Lin et al. 1996). Consequently, Chinese firms' ability to obtain government contracts critically depends on their political ties rather than merits. In the absence of strong legal and market institutions, most contracts are conducted privately through relationships such as personal ties and internal communications within political networks, rather than market mechanisms using legal procedures and public disclosures. Furthermore, instead of relying on market and legal institutions for protection, investors and other stakeholders are more readily turning to the government to seek compensation and bailout when the listed firms fall into financial trouble. Thus, we expect the value of political ties to be higher than the value of market credibility in China.

We measure the value of political ties and market credibility using market reactions to corporate scandals. Listed firms in China have often been accused of corporate misconduct such as financial misrepresentation, bribery, and asset misappropriation (Aharony, Lee, and Wong 2000; 
Chen and Yuan 2004; Fan et al. 2008). We expect the discovery of different types of scandals to reduce firm value through different channels. For firms involved with scandals signaling the loss of political ties, the key channel is the loss of contracting ability with the government and its related entities within their political networks. The ensuing failure to obtain these contracts will significantly reduce the firms' future cash flows, some of which include loss of economic rents from the political ties. For firms involved with scandals signaling the loss of market credibility, the key channel is the loss of contracting ability via market mechanisms. The inability to conduct arms-length contracts will lower firms' expected future cash flows. ${ }^{4}$ The increased expropriation risks due to the perceived loss of integrity lower the expected future payouts to outside shareholders, and therefore reduce firm value as well. ${ }^{5}$ Because political-based contracts are more prevalent in China, we expect that the reduction in expected future cash flows is greater, and therefore market reactions are more negative, for scandals signaling the destruction of political ties than for scandals signaling the destruction of market credibility. Thus, our hypothesis in alternative form is:

HYPOTHESIS. Corporate scandals that signal the destruction of political ties are associated with greater losses in firm value than corporate scandals that signal the destruction of market credibility.

\footnotetext{
${ }^{4}$ As suggested in Karpoff et al. (2008a), the scandals' negative firm value effect mainly comes from their destruction of firms' contracting mechanisms. Thus, we focus on the firm value effect via the contracting mechanisms, while controlling for the dollar amount of the scandals in our multivariate regression analysis.

${ }^{5}$ Even if the discovery of scandals may deter managers from stealing from the shareholders in the future, investors are still likely to expect a higher expropriation risk and hence lower future cash flows because by definition, they were not aware of managers' misconduct prior to the discovery of scandals. This reasoning is consistent with prior research on financial misrepresentation. Hribar and Jenkins $(2004,337)$ state "restatements of financial statements result in a substantial loss of market value..., this loss in market value has been attributed to a number of factors, including revisions of expected future earnings due to the non-existence of past earnings, revisions in expected growth rates, uncertainty regarding managerial competence and integrity, and perceptions about overall earnings quality."
} 
However, several arguments could also predict less negative market reactions to scandals signaling the destruction of political ties than to scandals signaling the destruction of market credibility. First, the economic reforms that move China towards a more market-based economy may make market scandals more detrimental to firm value. For example, prompted by a string of corporate scandals that emerged in 2001 (Shi and Weisert 2002), the CSRC issued the Code of Corporate Governance for Listed Companies in China in 2002, which expands the rights of minority shareholders, defines the duties of controlling shareholders and corporate boards, and increases information disclosure and transparency requirements. ${ }^{6}$ Second, in China it might be easier to rebuild political connections by hiring new directors with ready to use connections than to regain public trust, which is often on a fragile edge. These arguments indicate that it is essentially an open question as to whether the value of political ties is greater than the value of market credibility in China.

\section{Sample, classification of corporate scandals, and research design}

\section{Sample}

Our sample includes firms with enforcement actions against their Chairmen/CEOs by Chinese courts and firms with enforcement actions for financial misrepresentation by securities regulators. We begin our investigation period in 1997 because prior to this period the regulatory disclosure and media coverage of Chinese listed firms was relatively poor. We identify firms with enforcement actions against their Chairmen and/or CEOs by Chinese local and central courts via news searches. The sources of the key event dates for these scandals include $21^{\text {st }}$ Century Business

\footnotetext{
${ }^{6}$ Our additional analysis (untabulated) indicates that market reactions to political scandals generally become more negative subsequent to the reform in 2002. This is consistent with Haveman, Jia, Shi, and Wang (2013) that economic reform, without political reform, strengthens the value of political ties.
} 
Herald (for news coverage from 2001-2005) and online search engines such as www.google.com, www.baidu.com, and http://cn.yahoo.com/ (for news coverage prior to 2001). We identify firms with enforcement actions for financial misrepresentation by the CSRC and stock exchanges using data sources from China Security Market and Accounting Research (CSMAR), China Center for Economic Research (CCER), websites of the CSRC and stock exchanges, and firms' annual reports and public announcements. ${ }^{7}$ The sources of the key event dates for these firms include the following: public announcements by the listed firms and stock exchanges, monthly bulletins by the CSRC, and news reports from The China Securities Journal, Securities Times, Shanghai Securities News, and other major business and finance websites in China. We next obtain stock returns and financial data from the CSMAR database, and CEO and director profiles from the WIND financial database and companies' annual reports.

Our initial sample consists of 340 firms. For firms with multiple scandals, we keep the most recent ones (deleting 100 prior cases) so our test comprises distinct firms. Using the most recent scandal will likely bias against finding significant market reactions to the scandal because the market already reacted to the earlier scandal, but it ensures that our investigation of financing changes and director turnover subsequent to the scandal is not confounded by additional scandals. Finally, we delete four firms that do not have stock return data in CSMAR. These selection criteria result in a final sample of 236 firms.

\section{Classification of scandals and sample distribution}

Panel A of Table 1 lists the key types of scandals that involve the destruction of political ties and market credibility. This panel begins by describing scandals that involve the destruction of political ties. It shows that the major types of these scandals are managers bribing government

\footnotetext{
${ }^{7} \mathrm{We}$ include only financial misrepresentation because this type of scandal is the common focus of prior studies and most likely to damage firms' reporting credibility. For completeness, we also cross check the data with the list of accounting scandals used in Zhang (2007).
} 
officials (R1) and managers misappropriating state assets (R2), with R2 divided into three subgroups: tax evasion (R2a), managers of SOEs misappropriating firm assets (R2b), and managers of non-SOEs misappropriating firm assets in which the government has a minority stake (R2c). The loss of political ties associated with the R1/R2 scandals may affect firm value in two ways. First, the officials that are connected to the scandal firms likely have lost or will soon lose their political power and hence no longer be able to grant favors to the firm. Second, the arrest of the offending managers will also lead to the loss of political connections possessed by these managers. In both cases, the firm's ability to contract and seek rents from the government is damaged.

\section{Insert Table 1 About Here}

It is important to note that scandals associated with the destruction of political ties (i.e., R1/R2 scandals) do not necessarily involve the destruction of market credibility. Bribing government officials (R1) to acquire equity issuance rights or obtain government contracts (implicit and explicit) may help channel resources into the firm. In addition, while tax evasion (R2a) may reduce government revenues, it is not aimed to expropriate wealth from minority shareholders.

Only misappropriation of firm assets by managers of SOEs (R2b) or by managers of non-SOEs in which the government holds a minority stake (R2c) will directly hurt a firm's contracting ability with outside shareholders and stakeholders, and thus damage not only firms' political ties but also market credibility.

With regards to scandals that involve the destruction of market credibility, Panel A of Table 1 shows that the major types of these scandals are financial misrepresentation (M1) and misappropriation of firm assets (M2), with M2 divided into three subgroups: managers of nonSOEs misappropriating firm assets in which the government has no ownership (M2a), managers of SOEs misappropriating firm assets (M2b), and managers of non-SOEs misappropriating firm assets in which the government has a minority stake (M2c). The M1/M2 scandals reduce firm 
value in two ways. First, because accounting disclosure is critical for outside investors and other stakeholders to make business decisions and enforce contracts, misrepresentation negatively affects firms' contracting ability with these market participants. Second, because the perceived loss of integrity associated with misappropriation increases expropriation risks, it lowers the expected future payouts to outside shareholders.

Note that scandals that involve the destruction of market credibility (i.e., M1/M2 scandals) do not necessarily involve the destruction of political ties. ${ }^{8}$ Financial misrepresentation (M1) and asset misappropriation by managers of non-SOEs in which the government has no ownership (M2a) mainly affect contracting with market participants, not the political networks. As pointed out in our discussion of R2b and R2c above, only the misappropriation of firm assets by managers of SOEs (M2b) or by managers of non-SOEs in which the government holds a minority stake (M2c) will involve the destruction of market credibility as well as political ties.

Panel B of Table 1 presents the classification of our sample scandals. We regard scandals that suggest a direct offense against the government as primarily associated with the destruction of political ties, while scandals that suggest a direct offense against outside shareholders and stakeholders as primarily associated with the destruction of market credibility. Thus, while bribery of government officials (R1) and tax evasion (R2a) in political scandals raise doubts in the market about management integrity, we do not classify them as mixed scandals because they are not a direct offense against outside shareholders and stakeholders. Panel B shows that among our 236 sample firms, 31 are political scandal firms, 107 are mixed scandal firms, and 98 are market scandal firms. The panel also shows that the most common type of political scandal, mixed

\footnotetext{
${ }^{8}$ Accounting frauds, although they may embarrass the government, are unlikely to hurt or create mistrust between the government and the firm in China. In fact, Sun and Zhang (2006) find that some companies' executives got promoted after committing the frauds. To the extent that the accusations of committing accounting frauds are also resulting from political fights, it should bias against finding our hypothesized results.
} 
scandal, and market scandal is managers bribing government officials (R1, 28 firms), managers of SOEs misappropriating firm assets (R2b=M2b, 91 firms), and misrepresentation of financial statements (M1, 64 firms), respectively. Appendix 1 provides examples of political, mixed, and market scandals in our sample.

Table 2 presents the sample distribution by year and industry. Panel A shows an increasing trend in the number of scandals, which likely reflects greater regulatory oversight in the later period. For example, the sharp increase in the number of mixed and market scandals in 2002 is

likely due to increased CSRC enforcement actions in response to several high-profile scandals in 2001 (Shi and Weisert 2002). Panel B shows that the manufacturing sector, the biggest sector in Chinese economy, also has the largest number of corporate scandals.

\section{Insert Table 2 About Here}

\section{Research design}

We employ an event study methodology to test market reactions to corporate scandals, with the event date defined as the first public disclosure of the scandal. We measure market reactions using cumulative abnormal returns (CARs), calculated as stock returns minus returns of the market index on the listing stock exchange during a specified event window. For scandals with enforcement actions against Chairmen/CEOs by courts, we identify the event date as the date in which the press or the firm reports that the executive is arrested or brought in for questioning ('ShuangGui'), whichever is earlier. For scandals with enforcement actions by securities regulators, we identify the event date as the date in which the securities regulators or the firm announce the investigation inquiry, whichever is earlier.

While most event studies use a short event window (usually two or three days), we use relatively long event windows (from two months up to two years) for three reasons. First, the stock market in China often preempts the first public disclosure of the scandal due to information leakage and market response to events related to the scandal. For example, if a bureaucrat is 
arrested for accepting bribes from a firm, the market will expect an enforcement action against the executive of the bribing firm. Similarly, if a politician loses out in political competition, the market may expect enforcement actions against the managers that are connected to the politician. ${ }^{9}$ Thus, the firm's stock price may already impound this information prior to the first public disclosure of the executive's bribery charges. Second, if a firm is temporarily suspended for trading subsequent to the disclosure of the scandal, short event windows will fail to pick up the full price impact of the scandal. Third, while we identify the event date as the first public disclosure of the scandal, the date is generally either the date when the executive's arrest is reported or the date when an investigation inquiry by securities regulators is announced. A long event window will ensure that our results are not driven by the different nature of these event dates.

There are, however, concerns for using long event windows. One concern is that the likelihood of confounding events increases and causality becomes harder to establish as the window is expanded. To mitigate this concern, we perform analysis using alternative windows and examine other economic consequences subsequent to the scandals. Another concern is that CARs may be biased in capturing long-term abnormal returns. Thus, we use characteristics-adjusted returns (CSAR) to measure long-run returns for event windows greater than or equal to one year.

We test our hypothesis by regressing CARs/CSARs during event windows from two months up to two years on a dummy variable indicating political scandals, a dummy variable indicating mixed scandals, and several control variables. Our model includes the magnitude of the scandal to control for the severity of the scandal. In addition, we include average stock returns and accounting profitability prior to the scandal to control for the difference in prior performance. This is because political scandals may be associated with greater benefits and therefore better firm

\footnotetext{
${ }^{9}$ In such scenarios, the discovery of the scandals is collateral damage to the political process and serves as a signal for the loss of political ties (rather than the cause).
} 
performance prior to the public revelation of the scandals, which can in turn lead to more negative market reactions due to the reversal of firm performance. Following prior studies (Chen et al. 2005; Fan et al. 2008), we also control for the following firm characteristics, measured prior to the scandal, that may be associated with market reactions to corporate scandals: firm size, market-tobook, asset tangibility, and a dummy variable indicating whether a firm's majority shareholder is the government. Finally, we include a variable capturing provincial legal development to control for a firm's legal environments and dummy variables indicating industry membership to control for industry fixed effects. We define the variables in our analysis in Appendix 2. To mitigate the influence of outliers, we winsorize all scaled variables in our analyses at the top and bottom one percent of their distributions. Our regression model follows:

$$
\begin{gathered}
\text { CAR/CSAR } \left.=\beta_{0}+\beta_{1}(\text { Political scandal })+\beta_{2} \text { (Mixed scandal }\right)+\beta_{3}(\text { Magnitude of scandal })+ \\
\beta_{4}\left(\text { Stock return }_{\text {pre }}\right)+\beta_{5}\left(\text { ROA }_{\text {pre }}\right)+\beta_{6}\left(\text { Firm size }_{\text {pre }}\right)+\beta_{7}\left(\text { Market-to-book }_{\text {pre }}\right)+ \\
\beta_{8}\left(\text { Tangibility }_{\text {pre }}\right)+\beta_{9}(\text { SOE })+\beta_{10}(\text { Legal environment })+\beta_{m}(\text { DIndustry })+\varepsilon
\end{gathered}
$$

Our hypothesis predicts the coefficient on the dummy variable indicating political scandals $\left(\beta_{1}\right)$ and the coefficient on the dummy variable indicating mixed scandals $\left(\beta_{2}\right)$ to be negative. We draw our conclusions based on the comparison of political scandals and market scandals, as well as the comparison of mixed scandals and market scandals. While it is difficult to tell the relative value of political ties and market credibility by comparing mixed scandals and market scandals because mixed scandals signal the destruction of both political ties and market credibility, this comparison nonetheless provides corroborating evidence to the comparison between political and market scandals. Since we argue that political scandals are more damaging than market scandals due to the destruction of political ties, we would expect mixed scandals to also be more damaging than market scandals. While finding a significantly worse market reaction to the mixed scandals than to the market scandals alone would not provide much support to our hypothesis, finding an 
insignificant difference in the market reaction between mixed scandals and market scandals would cast doubt on the validity of our conclusions.

We do not compare market reactions between political and mixed scandals because we do not have predictions on the difference. While mixed scandals may be more damaging because they signal the destruction of both political ties and market credibility, political scandals can be more damaging because they typically also involve charges against government officials overseeing the firm. As shown in Panel B of Table 1, 28 out of the 31 political scandals relate to managers bribing government officials, but only one of the mixed scandals involves charges against government officials. Since the arrest of a connected government official has a direct negative effect on firms' political networks, political scandals can be as damaging if not more damaging than mixed scandals.

\section{Empirical results}

\section{Univariate analysis}

Table 3 presents the market reactions to corporate scandals during various event windows. The table shows that all types of corporate scandals are associated with negative stock returns during all event windows. In addition, consistent with our prediction, the negative stock returns are more pronounced for political and mixed scandals than market scandals from the two-month window up to the two-year window. For example, during the one-year event window (month -6 to month 6, with month 0 being the event date), the average CSAR is -29.8 percent for political scandals and -20.3 percent for mixed scandals, but only -8.3 percent for market scandals.

\section{Insert Table 3 About Here}

Figure 1 plots the average CSAR for each type of scandals from one year before the event date to one year after. Consistent with our hypothesis, the figure shows that the decline in firm value is most pronounced for political scandals and least pronounced for market scandals. Figure 1 
also shows a downward drift for all types of scandals prior to the event date (i.e., the first public disclosure of the scandal). This pattern is consistent with our previous discussion that in China the market often preempts the first public disclosure of the scandal due to information leakage and related events. In addition, the figure shows that the price decline persists longer for the political and mixed scandals than for the market scandals. This is likely due to that it takes time for the market to figure out the real impact of the scandals signaling the destruction of political ties.

Thus, these patterns provide further support to our use of long event window.

\section{Insert Figure 1 About Here}

\section{Hypothesis test}

Table 4 reports the results of our hypothesis test. Panel A of the table presents descriptive statistics. Consistent with our classification that market scandals include financial misrepresentation that materially misstate financial statements, the panel shows that magnitudes of scandals are higher for market scandals than for political and mixed scandals. ${ }^{10}$

\section{Insert Table 4 About Here}

Columns 1-4 of Table 4, Panel B present the regression results testing our hypothesis for event windows ranging from two months to two years. ${ }^{11}$ Consistent with our hypothesis, the coefficients on Political scandal and Mixed scandal are both significantly negative at $p \leq 0.10$ (two-tailed). ${ }^{12}$ These results indicate that political scandals and mixed scandals have worse market

\footnotetext{
${ }^{10}$ We assign a value of zero for 84 (36 percent) firms that we cannot find information for the magnitudes of scandals. As reported in a sensitivity test in Section 6, the results remain qualitatively the same after excluding these firms.

${ }^{11}$ We do not report the coefficients on the industry dummies in this and all subsequent regressions in the interest of parsimony.

${ }^{12}$ For completeness, we also perform analysis using daily returns over event windows $(-1,1)$ days, $(-5,5)$ days, $(-10,+10)$ days, and $(-15,+15)$ days. The coefficients on the dummy variables indicating political scandals and mixed scandals are generally insignificant, except for the coefficient on the dummy variable indicating mixed scandals during the 20-day and 30-day event window. The weaker results are not surprising given the reasons discussed in the preceding section.
} 
reactions than market scandals, suggesting that scandals signaling the destruction of a firm's political ties result in greater losses in firm value than scandals signaling the destruction of a firm's market credibility. Overall, our results are consistent with the notion that the Chinese economy is more political-based than market-based.

\section{Analysis further controlling for legal penalties}

An alternative explanation for our results is that political and mixed scandals are associated with more severe legal penalties than market scandals. Political scandals such as bribery may be an excuse of one clique eliminating a competing clique and therefore involve more severe legal sanctions than market scandals. In addition, regulators may impose larger penalties on firms for cheating the government than for cheating investors. If scandals involve bribery of government officials or misappropriation of state assets are punished more severely, investors would expect these scandals to be more serious (Becker and Landes 1974). Consequently, the stock market would react more negatively to political scandals and mixed scandals than to market scandals. Thus, we perform analysis further controlling for legal sanctions. We note, however, this analysis assumes that investors can foresee the outcomes even though the legal proceedings typically take years and often fall beyond our event windows.

The last several rows of Panel A of Table 4 report legal penalties on firms and individuals across the three types of scandals. For legal penalties on firms, these rows show that political scandals are associated with the largest monetary penalty while market scandals are associated with the smallest monetary penalty. In contrast to monetary penalty, market scandals are associated with higher non-monetary penalty than mixed scandals and political scandals. For legal penalties on individuals, mixed scandals are associated with the largest monetary penalty while

market scandals are associated with the smallest monetary penalty. In addition, mixed scandals are 
generally associated with the most severe non-monetary penalties while market scandals are associated with the least severe non-monetary penalties. ${ }^{13}$

Columns 5-8 of Table 4, Panel B report results re-estimating equation (1) after further controlling for monetary and non-monetary penalties imposed on firms and individuals. We note that by controlling for individual penalties, we potentially bias against finding our hypothesized results. This is because we expect that political and mixed scandals hurt a firm's contracting ability through the political persecution against their managers and destroying their political connections. Thus, these individual penalties could proxy for the severity of the damage in the firm's contracting ability. Nonetheless, the coefficient on the dummy variable indicating political scandals and the coefficient on the dummy variable indicating mixed scandals remain significantly negative at $p \leq 0.10$ (two-tailed). In addition, the coefficient on a firm's monetary penalties is significantly negative, suggesting that the market reacts more negatively to firms with greater penalties. These columns also show that while the coefficient on the dummy variable indicating criticism and restriction of employment in securities markets is significantly negative in some specifications, the coefficient on individual monetary penalty is significantly positive in some specifications. This finding suggests that stock market reacts more negatively to scandals that limit an executive's current and future employment opportunities, but does not react negatively to scandals that involve more monetary penalties on executives. While it is somewhat surprising that the coefficients on the dummy variable indicating imprisonment and death penalty are insignificant, this is likely because those penalties typically involve lengthy legal proceedings that last several years. Since such severe outcomes are difficult to predict upon the discovery of the scandals and in subsequent months within the event windows, it is not surprising that we find no

\footnotetext{
${ }^{13}$ In untabulated results, we find that seven of our sample firms were cleared of wrongdoing at the end of investigation.
} 
market reaction related to these outcomes. Overall, the analysis after controlling for legal penalties continues to find results supporting our hypothesis.

\section{Market reaction to corporate scandals conditional on political dependence}

One concern for the inference from our hypothesis test is that the revelation of political scandals may result from the purge after political turmoil, which not only damages political networks, but also hurts economic activities. Thus, the more negative market reaction to political and mixed scandals may be due to unfavorable macro economic conditions, rather than to the destruction of scandal firms' political networks. To address this concern, we perform analysis examining market reactions to corporate scandals conditional on firms' political dependence. While our arguments would predict that the negative market reaction to the political and mixed scandals is more pronounced among firms with stronger political dependence, the argument of macro economic conditions would predict no differences.

We perform this analysis by expanding our equation (1) after adding a dummy variable indicating strong political dependence and its interaction terms with the dummy variables indicating political and mixed scandals. We use two measures, provincial development and political connectedness, to proxy for political dependence. Our first measure, provincial development, equals the sum of a firm's provincial legal environment index and market development index. The notion that underlies this measure is that firms in provinces with weaker legal environments and market development are more dependent on political networks to conduct business. We classify firms with a score below the sample province-level median as having strong political dependence (i.e., weak provincial development). Our second measure, political connectedness, is a firm-level measure and equals the sum of the following three binary variables: (1) whether a firm's percentage of politically connected directors is above the sample firm-level median, (2) whether a firm's loans from state-owned banks is above the sample firm-level median, and (3) whether a firm's government subsidy is above the sample firm-level median. Since firms 
with a higher value of political connectedness are more dependent on political networks, we classify firms with a score above the sample firm-level median as having strong political dependence (i.e., strong political connectedness).

Panel A of Table 5 reports descriptive statistics for our conditional variables. Panel B reports the regression results using weak provincial development to proxy for strong political dependence. We expect the coefficients on the two variables of interest, the interaction terms Political scandal $\times$ Weak provincial development $\left(\beta_{4}\right)$ and Mixed scandal $\times$ Weak provincial development $\left(\beta_{5}\right)$, to be negative. $\beta_{4}\left(\beta_{5}\right)$ captures the difference in market reactions between political scandals and market scandals (between mixed scandals and market scandals) in less developed provinces, relative to the corresponding difference in more developed provinces. Consistent with our predictions, Panel B shows that $\beta_{4}$ and $\beta_{5}$ are both significantly negative at $p \leq 0.10$ (two-tailed) in all event windows except the longest one.

To better understand the interpretation of the coefficients the last four rows of Table 5, Panel B report the differences in market reactions between different types of scandals based on whether the firms are in more versus less developed provinces. The first row shows that the difference in market reactions between political scandals and market scandals for firms operating in more developed provinces, $\beta_{1}$, is insignificant. In contrast, the second row shows that the difference in market reactions between political and market scandals in less developed provinces, $\beta_{1}+\beta_{4}$, is significantly negative in all event windows. Importantly, the difference in market reactions to the two types of scandals in less developed provinces relative to the corresponding difference in more developed provinces, $\beta_{4}$, is significantly negative, suggesting that the greater negative market reactions associated with political scandals (relative to market scandals) are primarily driven by firms that operate in less developed regions. Similarly, the bottom two rows show that the greater negative market reactions associated with mixed scandals (relative to market scandals) are primarily driven by firms that operate in less developed regions. 
Panel C of Table 5 reports the regression results using strong political connectedness to proxy for strong political dependence. Also consistent with our prediction, Panel C shows that the coefficient on Political scandal $\times$ Strong political connectedness is significantly negative at $p \leq$ 0.10 (two-tailed) in all event windows except the four-month window, and the coefficient on Mixed scandal $\times$ Strong political connectedness is significantly negative at $p \leq 0.10$ (two-tailed) in all event windows except the longest one. In addition, the last four rows of Panel C report the differences in market reactions between different types of scandals based on whether the firms have weak versus strong political connections. Consistent with the evidence in Panel B, we also find that the greater negative market reactions associated with political and mixed scandals (relative to market scandals) are primarily driven by firms with strong political connections. ${ }^{14}$

\section{Insert Table 5 About Here}

\section{Post-scandal operating performance, financing sources, and board structures}

\section{Impact of scandals on operating performance}

One reason that political and mixed scandals have more negative market reactions may be that investors expect firms involved with these types of scandals to have more negative operating performance subsequent to the scandals. Such decline in performance is expected due to the loss in political-based contracts and the related rents associated with them. To shed light on this explanation, we examine the impact of scandals on firms' post-scandal operating performance and

\footnotetext{
${ }^{14} \mathrm{We}$ also perform additional analysis examining market reactions to market scandals conditional on the development of market. Our market development index is based on the 2005 NERI index of marketization of China's provinces and calculated as one minus total public expenditure divided by provincial GDP (after normalized to a range of 0-10). Our analysis (untabulated) regresses CARs/CSARs on a dummy variable indicating market scandals, a dummy variable indicating strong market development, their interaction term, and control variables. We find that the interaction term is significantly negative in all event windows except the longest one, suggesting that market scandal firms in provinces with more developed market experience more negative market reactions.
} 
sales growth, as captured by changes in ROA and sales growth from the three years before to three years after the event (excluding the event year).

We perform this test by regressing changes in ROA (or changes in sales growth) on a dummy variable indicating political scandals, a dummy variable indicating mixed scandals, and control variables in our equation (1). Panel A of Table 6 provides descriptive statistics on the additional variables used in this analysis. ${ }^{15}$ Panel B provides regression results. Consistent with our expectation, the analysis finds that the coefficients on Political scandal and Mixed scandal are significantly negative at $p \leq 0.10$ (two-tailed) in both models. Thus, this analysis provides corroborating evidence to our main inferences that firms involved with political and mixed scandals have worse profitability and sales growth subsequent to the scandals. ${ }^{16}$

\section{Insert Table 6 About Here}

\section{Impact of scandals on financing sources}

Another reason that political and mixed scandals have more negative market reactions may be that investors expect firms involved with these scandals to experience larger decreases in loans from state-owned banks. Prior studies suggest that a major financing source for Chinese firms is loans from state-owned banks (Fan et al. 2008; Chen, Chen, Lobo, and Wang 2010). If political and mixed scandals result in greater losses of political ties, we would expect firms involved with these scandals to experience larger decreases in loans from state-owned banks (Faccio 2006).

To test the impact of scandals on loans from state-owned banks, we manually collect loan information from the footnotes of financial statements. In addition to the amount and sources of loans, we also collect the incidents of overdue borrowing. Many borrowers in China rely on short-

\footnotetext{
${ }^{15}$ The number of observations for the analysis in Table 6 is slightly smaller than that in Table 4 because there is no data on post-scandal operating performance for delisted firms.

${ }^{16} \mathrm{We}$ also perform analysis on changes in investment, but do not find any significance across different types of scandals.
} 
term debt to finance long-term projects and have to renew their borrowings year by year. If a bank is concerned about a firm's credit worthiness, it would refuse to renew the loan, thereby leading to overdue borrowing for the firm. In China, "overdue" borrowing is an important trigger and a hard indicator that the borrower's credit worthiness will be downgraded.

We test our prediction by regressing changes in financing from state-owned banks on a dummy variable indicating political scandals and a dummy variable indicating mixed scandals. We also include several control variables that are likely to affect changes in firms' financing sources subsequent to the scandal: (1) the magnitude of scandals, (2) changes in firm characteristics on profitability, size, market-to-book ratio, and asset tangibility, (3) a dummy variable indicating SOE, (4) a firm's legal environment, and (5) dummy variables indicating industry membership and years. Appendix 2 provides detailed variable definitions. Our regression model follows:

Changes in loans from state-owned banks $=\beta_{0}+\beta_{1}($ Political scandal $)+\beta_{2}($ Mixed scandal $)+$ $\beta_{3}($ Magnitude of scandal $)+\beta_{4}(\Delta R O A)+\beta_{5}(\Delta$ Firm size $)+\beta_{6}(\Delta$ Market-to-book $)+$ $\beta_{7}(\Delta$ Tangibility $)+\beta_{8}($ SOE $)+\beta_{9}($ Legal environment $)+\beta_{m}($ DIndustry $)+\beta_{n}($ DYear $)+\varepsilon$

Panel A of Table 7 provides descriptive statistics on the additional variables used in this analysis. The panel shows that, on average, loans from state-owned banks increase subsequent to the public disclosure of scandals. This finding is likely due to the increasing trend of debt during our sample period. ${ }^{17}$

\section{Insert Table 7 About Here}

Panel B of Table 7 presents the regression results. The panel shows that firms with political and mixed scandals experience more decreases in loans from state-owned banks, as well as in an

\footnotetext{
${ }^{17}$ Fan et al. (2008) also find that short-term debt increases among their sample firms involved with 23 high-level government officer corruption cases from 1995 to 2003.
} 
additional measure including loans from local governments. The panel also shows that firms with political scandals experience more increases in overdue borrowing from state-owned banks. For completeness, the final column of the panel reports the result analyzing changes in total debt. In contrast to our results on loans from state-owned banks, we do not find changes in total debt to be significantly different between firms with political and mixed scandals and firms with market scandals, suggesting that the results on loans from state-owned banks are unlikely to be driven by the differences in total debt financing. In summary, these findings corroborate the results from our hypothesis test and suggest that political and mixed scandals result in greater losses in political ties that are essential for Chinese firms to obtain state financing.

\section{Impact of scandals on board structure}

The underlying assumption of our hypothesis is that compared to market scandals, political and mixed scandals are more damaging in China because they signal the destruction of firms' political networks. To provide further corroborating evidence, we examine the impact of political and mixed scandals on firms' board structures. We expect firms with political and mixed scandals to experience a greater shock to their political networks as reflected by departure of their political directors (i.e., directors who are politically connected) subsequent to the event.

To test our prediction we regress departure of political directors on a dummy variable indicating political scandals, a dummy variable indicating mixed scandals, and control variables as specified in equation (2). We measure departure of political directors as the percentage of political directors leaving the firm during the three years subsequent to the event. ${ }^{18}$

Panel A of Table 8 presents descriptive statistics on the additional variables used in this analysis. The panel shows that on average, 15 percent of political directors depart the scandal

\footnotetext{
${ }^{18} \mathrm{We}$ focus on three years, a typically term period for directors in China, although they are often reappointed.
} 
firms in the three years subsequent to the event. Column 1 of Panel B, Table 8 presents the results. Consistent with our prediction, we find that political and mixed scandals are associated with a greater departure of political directors. For completeness, we also analyze the entrance of political directors, measured as the percentage of new political directors added to the board during the three years subsequent to the event period. Column 2 of the panel shows that political and mixed scandals are also associated with a greater percentage of new political directors. Overall, these findings indicate that firms with political and mixed scandals experience both greater destruction and realignment to their political networks.

\section{Insert Table 8 About Here}

Finally, we investigate whether a political scandal firm that successfully repairs its political network experiences a better post-scandal return. We capture the success of a firm's effort to repair its political network by a dummy variable indicating a net gain of political director (i.e., the accumulated entrance of political directors is above or equal to the accumulated departure of political directors in the three years subsequent to the event period). We then regress cumulative market returns during the event window $[-1,36]$ months on the dummy variables indicating political scandals and mixed scandals, the dummy variable indicating net gain of political directors, their interaction terms, and control variables. Column 3 of Panel B shows that the coefficient on Political scandal*Net gain of political directors is significantly positive. This finding is consistent with our expectation and suggests that a political scandal firm that successfully repairs its political network is associated with a better post-scandal return. We caution, however, that this analysis does not show causality between director changes and stock returns. The positive association between post-scandal returns and a net gain of political directors can also be because firms with better stock returns are more able to attract new political directors to join their boards. 


\section{Sensitivity tests}

\section{Alternative event windows}

Our primary analysis in Table 4 uses long windows from two months up to two years surrounding the event because it is difficult to identify when the market learns about the scandals in China. One concern from starting the event window several months prior to the disclosure date is that firms may commit scandals after experiencing poor returns, thereby confounding the interpretation of our results. To address this concern, we repeat our analysis in Panel B of Table 4 after using alternative windows starting at one month prior to the public disclosure of the scandal: $(-1,1),(-1,6),(-1,12)$, and $(-1,36)$ months. The results are qualitatively identical as those reported in Table $4 .{ }^{19}$

\section{Alternative treatments of firms with multiple scandals}

We repeat our analysis after using two alternative treatments of firms with multiple scandals: including all scandals as separate events and keeping the earliest scandal. The results are qualitatively identical as those reported in Table 4.

\section{Alternative return measures}

We repeat our analysis in Panel B of Table 4 after using buy-and-hold abnormal returns to calculate long-term abnormal returns (Barber and Lyon 1997). The results from this analysis are qualitatively identical as those reported in Table 4, except that the coefficient on the dummy variable indicating political scandals becomes insignificant in the longest event window.

\section{Alternative treatments of delisted firms}

We assess whether our results are sensitive to the treatment of delisted firms by repeating our analysis in Panel B of Table 4 after excluding these firms, or after controlling for a dummy

\footnotetext{
${ }^{19}$ By 'qualitatively identical' to the results in Table 4 we mean that the coefficient on the dummy variable indicating political scandals and the coefficient on the dummy variable indicating mixed scandals are negative and significant at $p \leq 0.10$ (two-tailed) during all event windows longer than two months.
} 
variable indicating delisting. ${ }^{20}$ The results from this analysis are qualitatively identical to those reported in Table 4.

\section{Excluding scandals enforced by the Chinese stock exchanges}

We repeat our analysis in Panel B of Table 4 after excluding from our sample five scandal cases enforced by the stock exchanges, and find qualitatively identical results.

\section{Restricting firms to those with non-missing data on magnitude of scandals}

We perform analysis after excluding firms with missing data on magnitudes of scandals. While the sample size of this analysis is reduced by more than 30 percent, the results from this analysis are qualitatively identical to those reported in Table 4, except that the coefficient on the dummy variable indicating political scandals becomes insignificant in the two-month and fourmonth event windows.

\section{Restricting firms to SOEs}

We repeat our analysis after deleting 45 non-SOEs. The results from this analysis are qualitatively identical to those reported in Table 4, except that the coefficient on the dummy variable indicating political scandals becomes insignificant in the two-month and four-month event windows.

\section{Excluding years with influential numbers of observations}

We repeat our analysis after excluding three years with influential numbers of observations, 2001, 2002, and 2005, one at a time. The results from this analysis are qualitatively identical to those reported in Table 4.

\section{Conclusion}

\footnotetext{
${ }^{20}$ In our sample, 24 firms delisted one or two years after the disclosure of the scandal. Among them, five are political scandal firms, 12 are mixed scandal firms, and seven are market scandal firms. Also, we do not find that political scandals or mixed scandals are statistically associated with more delisting than market scandals in our sample.
} 
This paper compares the value of political ties and market credibility in China. Using a sample of enforcement actions by the Chinese courts and securities regulators from 1997-2005, we categorize each corporate scandal by whether it is primarily associated with the destruction of a firm's political ties (political scandals), both political ties and market credibility (mixed scandals), or market credibility (market scandals). We document that scandals signaling the loss of firms' political ties (political and mixed scandals) lead to more negative stock returns than scandals signaling the loss of firm's market credibility (market scandals). In addition, the greater negative market reactions associated with political and mixed scandals are primarily driven by firms that rely more on political networks. We also find that political and mixed scandals are associated with a larger decrease in operating performance and financing from state-owned banks, and a greater departure of political directors subsequent to the scandal.

A caveat of our study is that we only aim to measure the market impact of scandals when they are subject to an enforcement action. Thus, we do not speak to the economic significance of corporate misconducts that are undiscovered or are not subject to an enforcement action by courts or securities regulators. We conjecture that political scandals are more likely to be associated with firms that have weaker political ties because firms with stronger ties can better fend off corruption investigation. In contrast, market scandals are unlikely to experience such an enforcement bias because these scandals do not have significant political consequences. Thus, our findings may understate the effect of political ties relative to market credibility in China.

Overall, our study is among the first to compare the price effects and other economic consequences of corporate scandals that involve the destruction of political ties versus market credibility in emerging markets. By using China as a unique setting where both political scandals and market scandals are common and contracts are primarily based on relationships with the government, we shed light on the relative importance of political ties and market credibility in emerging markets. 


\section{Appendix 1}

List of sample firms involved with political, mixed, and market scandals

\begin{tabular}{|c|c|c|c|}
\hline & Company name & Code & Description \\
\hline \multicolumn{4}{|c|}{ Political scandals } \\
\hline 1 & Little Swan Co. & 000418 & Managers bribing government officials [R1] \\
\hline 2 & Weifu High-Technology Co. & 000581 & Managers bribing government officials [R1] \\
\hline 3 & Sichuan Topsoft Investment Co. & 000583 & Managers bribing government officials [R1] \\
\hline 4 & Far East Industrial Stock Co. & 000681 & Managers bribing government officials [R1] \\
\hline 5 & Jiangnan Mould \& Plastic Tech. Co. & 000700 & Managers bribing government officials [R1] \\
\hline 6 & Jiangsu Fasten Co. & 000890 & Managers bribing government officials [R1] \\
\hline 7 & Jiangsu Sunshine Co. & 600220 & Managers bribing government officials [R1] \\
\hline 8 & $\begin{array}{l}\text { Guangdong Yinghao Science-Technology } \\
\text { \& Education Investment Co. }\end{array}$ & 600672 & Managers bribing government officials [R1] \\
\hline 9 & Erdos Group & 600295 & Tax Evasion [R2a] \\
\hline 10 & Tibet Summit Industry Co. & 600338 & Tax Evasion [R2a] \\
\hline \multicolumn{4}{|c|}{ Mixed scandals } \\
\hline 1 & Shenzhen Energy Group & 000027 & Managers of SOEs misappropriating firm assets [R2b/M2b] \\
\hline 2 & Shenzhen Yan Tian Port Holding Co. & 000088 & Managers of SOEs misappropriating firm assets [R2b/M2b] \\
\hline 3 & Sinopec Shengli Oil Field Dynamic Co. & 000406 & Managers of SOEs misappropriating firm assets [R2b/M2b] \\
\hline 4 & $\begin{array}{l}\text { Guangzhou Baiyunshan Pharmaceutical } \\
\text { Co. }\end{array}$ & 000522 & Managers of SOEs misappropriating firm assets [R2b/M2b] \\
\hline 5 & Xining Special Steel Co. & 600117 & Managers of SOEs misappropriating firm assets [R2b/M2b] \\
\hline 6 & Xiamen Motor Co. & 600686 & Managers of SOEs misappropriating firm assets [R2b/M2b] \\
\hline 7 & Xiamen Engineering Machinery Co. & 600815 & Managers of SOEs misappropriating firm assets [R2b/M2b] \\
\hline 8 & $\begin{array}{l}\text { Yueyang Hengli Air-Cooling Equipment } \\
\text { Co. }\end{array}$ & 000622 & $\begin{array}{l}\text { Mangers of non-SOEs in which government maintains a } \\
\text { minority stake misappropriating firm assets [R } 2 \mathrm{c} / \mathrm{M} 2 \mathrm{c}]\end{array}$ \\
\hline 9 & $\begin{array}{l}\text { Shenzhen Dawncom Business } \\
\text { Technology and Service Co. }\end{array}$ & 000863 & $\begin{array}{l}\text { Mangers of non-SOEs in which government maintains a } \\
\text { minority stake misappropriating firm assets }[\mathrm{R} 2 \mathrm{c} / \mathrm{M} 2 \mathrm{c}]\end{array}$ \\
\hline 10 & $\begin{array}{l}\text { Century Zhongtian Investment Joint } \\
\text { Stock Co. }\end{array}$ & 000540 & $\begin{array}{l}\text { Manager bribing government officials and manipulating } \\
\text { accounting numbers to conceal the bribe }[\mathrm{R} 1+\mathrm{M} 1]\end{array}$ \\
\hline \multicolumn{4}{|c|}{ Market scandals } \\
\hline 1 & Zhuhai Shining Metals Group Inc. & 000405 & Financial misrepresentation [M1] \\
\hline 2 & Stone Group Hi-Tech Co. & 000409 & Financial misrepresentation [M1] \\
\hline 3 & Zhang Jia Jie Tourism Development Co. & 000430 & Financial misrepresentation [M1] \\
\hline 4 & Hai Nan New Energy Co. & 000502 & Financial misrepresentation [M1] \\
\hline 5 & Henan Yinge Industrial Inv. Holding Co. & 600069 & Financial misrepresentation [M1] \\
\hline 6 & Hunan Jinjian Cereals Industry Co. & 600127 & Financial misrepresentation [M1] \\
\hline 7 & USTC Chuangxin Co. & 600551 & Financial misrepresentation [M1] \\
\hline 8 & Jiangsu Chinese.com Co. & 000805 & Managers of non-SOEs misappropriating firm assets [M2a] \\
\hline 9 & Fujian Shenlong Development Co. & 600659 & Managers of non-SOEs misappropriating firm assets [M2a] \\
\hline 10 & Zhejiang Xinlian Co. & 600899 & Managers of non-SOEs misappropriating firm assets [M2a] \\
\hline
\end{tabular}




\section{Appendix 2}

\section{Variable definitions}

\section{Variables of interest}

$C A R=$ Cumulative abnormal return, calculated by cumulating stock returns minus returns of the market index on the listing stock exchange in various event windows.

$C S A R=$ Characteristics-adjusted abnormal return, calculated by cumulating stock returns minus characteristics-matched benchmark returns (Daniel, Grinblatt, Titman, and Wermers 1997). To construct the benchmark return, we group the universe of stocks listed on stock exchanges into two quintile groupings based on the firm's size and book-to-market ratio. The five by five sorting results in a total of 25 portfolios. Each scandal firm is assigned to a portfolio according to its size and book-to-market ratio and the abnormal return is calculated by subtracting the portfolio's return from the firm's return.

Political scandal $=$ An indicator variable equal to one if the firm is involved in a political scandal. Mixed scandal = An indicator variable equal to one if the firm is involved in a mixed scandal.

\section{Control variables}

Magnitude of scandal $=$ The amount of bribery, tax evasion, misappropriation, or financial misrepresentation, divided by total assets prior to the scandal.

Stock return $_{\text {pre }}=$ Average yearly stock returns during the three years prior to the event.

$R O A_{\text {pre }}=$ Average ratio of net income to total assets during the three years prior to the event.

Firm size $e_{\text {pre }}=$ Natural logarithm of average total assets (in RMB) during the three years prior to the event.

Market-to-book $k_{\text {pre }}=$ Average ratio of market value to book value of assets during the three years prior to the event.

Tangibility $_{\text {pre }}=$ Average ratio of fixed assets to total assets during the three years prior to the event.

$S O E=$ A dummy variable equal to one if the firm is owned by the government, and zero otherwise.

Legal environment $=$ An index that captures the legal development level of each province, based on the 2005 National Economic Research Institute (NERI) Index of Marketization of China's provinces. The index is based on the average of the following three components (after normalizing each component to a range of 0-10): (1) the number of lawyers as a percentage of the province's population; (2) the efficiency of local courts, as captured by the percentage of lawsuits pursued by the courts; and (3) the extent of property rights protection, as captured by the number of patents granted per research and development personnel. Higher values represent stronger legal environments.

Industry dummy = Variables indicating industry membership based on the CSRC classification Monetary penalty $=$ The amount of legal penalty divided by total assets prior to the scandal.

\section{Conditional variables}

Weak provincial development $=$ A variable indicating whether the sum of the legal environment index and market development index for a firm's province, based on the 2005 National Economic Research Institute (NERI) Index of Marketization of China, is below the sample province-level median. 


\section{Appendix 2, continued}

Strong political connectedness $=$ A variable indicating whether the firm has higher than the median value of the summary measure of the following three binary variables: (1) whether its percentage of politically connected directors is above the sample firm-level median, (2) whether its loans from state-owned banks is above the sample firm-level median, and (3) whether its government subsidy is above the sample firm-level median.

Political director $=$ Average percentage of politically connected board members during the three years prior to the event year. A board member is defined as politically connected if he/she is a current or former officer of the central government, a local government, or the military.

Loan from state-owned banks = An indicator variable equal to one if a firm's loans from stateowned banks divided by total assets is above the sample firm-level median.

Government subsidy = An indicator variable equal to one if a firm's government subsidies divided by total assets is above the sample firm-level median.

\section{Change in performance, growth, and financing sources}

$\triangle R O A=$ Change in average ratio of net income to total assets from the three years before to three years after the event (excluding the event year).

$\Delta$ Sales growth $=$ Change in average ratio of sales to total assets from the three years before to three years after the event (excluding the event year).

$\triangle$ Loans from $S B=$ Change in average ratio of loans from state-owned banks divided by total assets, from the three years before to three years after the event (excluding the event year).

$\Delta$ (Loans from $S B$ and government $)=$ Change in average ratio of loans from state-owned banks plus loans from local government, divided by total assets, from the three years before to three years after the event (excluding the event year).

$\triangle$ Overdue borrowing from $S B=$ Changes in the incidents of borrowing that is indicated as overdue, from the three years before to three years after the event (excluding the event year). The incident of overdue borrowing is measured as the sum of two dummy variables, with one indicating an overdue short-term debt and the other indicating an overdue long-term debt.

$\Delta$ Total debt $=$ Change in average ratio of short-term debt plus long-term debt, divided by total assets, from the three years before to three years after the event (excluding the event year).

\section{Changes in board structures}

Departure of political directors $=$ Accumulated departure rate of political directors in the three years subsequent to the event period, where departure rate is measured as the number of directors leaving the firm divided by the size of the board.

Entrance of political directors $=$ Accumulated entrance rate of political directors in the three years subsequent to the event period, where entrance rate is measured as the number of directors entering the firm divided by the size of the board.

Net gain of political directors $=$ An indicator variable equal to one if the entrance of political directors is above or equal to the departure of political directors.

\section{Additional control variables}

$\Delta$ Firm size $=$ Change in nature logarithm of average total assets in RMB from the three years before to three years after the event (excluding the event year).

$\Delta$ Market-to-book $=$ Change in average ratio of market value to book value of assets from the three years before to three years after the event (excluding the event year).

$\Delta$ Tangibility $=$ Change in average ratio of fixed assets to total assets from the three years before to three years after the event (excluding the event year).

Year dummy = Dummy variables indicating years. 


\section{References}

Aharony, J., J. Lee, and T.J. Wong. 2000. Financial package of IPO firms in China. Journal of Accounting Research 38: 103-126.

Allen, F., J. Qian, and M. Qian. 2005. Law, finance, and economic growth in China. Journal of Financial Economics 77: 57-116.

Barber, B., and J.D. Lyon. 1997. Detecting long-run abnormal stock returns: the empirical power and specification of test statistics. Journal of Financial Economics 43: 341-372.

Becker, G.S., and W.M. Landes. 1974. Essays in the Economics of Crime and Punishment. National Bureau of Economic Research. New York.

Chaney, P.K., M. Faccio, and D. Parsley. 2011. The quality of accounting information in politically connected firms. Journal of Accounting and Economics 51: 58-76.

Chen, C., J. Z. Chen, G.J. Lobo, and Y. Wang. 2010. Association between borrower and lender state ownership and accounting conservatism. Journal of Accounting Research 48: 973-1014.

Chen, G., M. Firth, D. Gao, and O. Rui. 2005. Is China's securities regulatory agency a toothless tiger? Evidence from enforcement actions. Journal of Accounting and Public Policy 24: 451488.

Chen, K., and H. Yuan. 2004. Earnings management and capital resource allocation: Evidence from China's accounting-based regulation of rights issues. The Accounting Review 74: 645665.

Daniel, K. M. Grinblatt, S. Titman, and R. Wermers. 1997. Measuring mutual fund performance with characteristics-based benchmarks. The Journal of Finance 52: 1035-1058.

DeFond, M.L., T.J. Wong, and S. Li. 2000. The impact of improved auditor independence on audit market concentration in China. Journal of Accounting and Economics 28: 269-305.

Dinc, I. S. 2005. Politicians and banks: political influences on government-owned banks in emerging countries. Journal of Financial Economics 77: 453-479. 
Faccio, M. 2006. Politically connected firms. American Economic Review 96: 369-386.

Faccio M., R. Masulis, and J.J. McConnell. 2006. Political connections and corporate bailouts. The Journal of Finance 61: 2597-2635.

Fan, J., O. Rui, and M. Zhao. 2008. Public governance and corporate finance: evidence from corruption cases. Journal of Comparative Economics 36: 343-364.

Fan, J., T.J. Wong, and T. Zhang, 2007. Politically connected CEOs, corporate governance, and post-IPO performance of China's newly partially privatized firms. Journal of Financial Economics 84: 330-357.

Fisman, R. 2001. Estimating the value of political connections. American Economic Review 91: $1095-1102$.

Haveman, H., N. Jia, J. Shi, and Y. Wang. 2013. China's economic transition and the value of firms' political connections: A longitudinal study of publicly listed firms. Working paper, University of California at Berkeley, Australian National University and University of Southern California.

Hribar, P., and N. Jenkins. 2004. The effect of accounting restatements on earnings revisions and the estimated cost of capital. Review of Accounting Studies 9: 337-356.

Hung, M., T.J. Wong, and T. Zhang. 2012. Political considerations in the decision of Chinese SOEs to list in Hong Kong. Journal of Accounting and Economics 53: 435-449

Johnson, S., and T. Mitton. 2003. Cronyism and capital controls: evidence from Malaysia. Journal of Financial Economics 67: 351-382.

Karpoff, J., D.S. Lee, and G. Martin. 2008a. The cost to firms of cooking the books. Journal of Financial and Quantitative Analysis 43: 581-612.

Karpoff, J., D.S. Lee, and G. Martin. 2008b. The consequences to managers for financial misrepresentation. Journal of Financial Economics 88: 193-215. 
Kedia, S., and T. Philippon. 2009. The economics of fraudulent accounting. Review of Financial Studies 22: 2169-2199.

La Porta, R., R. Lopez-de-Silanes, A. Shleifer, and R.W. Vishny. 1998. Law and finance. Journal of Political Economy 106: 1113-1155.

Lennox, C., and J. Pittman. 2010. Big five audits and accounting fraud. Contemporary Accounting Research 27: 209-247

Leuz, C., and F. Oberholzer-Gee. 2006. Political relationships, global financing, and corporate transparency: evidence from Indonesia. Journal of Financial Economics 81: 411-439.

Lin, J. Y., F. Cai, and Z. Li. 1996. The China Miracle: Development Strategy and Economic Reform. Chinese University Press, Hong Kong.

Miller, G. S. 2006. The press as a watchdog for accounting fraud. Journal of Accounting Research 44: 1-33.

Palmrose, Z. V., V. Richardson, and S. Scholz. 2004. Determinants of market reactions to restatement announcements. Journal of Accounting and Economics 37: 59-89.

Shi, S. and D. Weisert. 2002. Corporate governance with Chinese characteristics. The China Business Review 29: 40.

Srinivasan, S. 2005. Consequences of financial reporting failure for outside directors: Evidence from accounting restatements and audit committee members. Journal of Accounting Research 43: 291-334.

Sun, P. and Y. Zhang. 2006. Is there penalty for crime? corporate scandal and management turnover in China. Working paper. Peking University.

Wang, Q., T.J. Wong, and L. Xia. 2008. State ownership, institutional environment and auditor choice: evidence from China. Journal of Accounting and Economics 46: 112-134.

Weber, J., M. Willenborg, and J. Zhang. 2008. Does auditor reputation matter? The case of KPMG Germany and Comroad AG. Journal of Accounting Research 46: 941-972. 
Zhang, P. 2007. An empirical study of intra-industry effect of corporate scandal announcements in China. Working paper, The Chinese University of Hong Kong. 
TABLE 1

\section{Classification of scandals}

Panel A: Key types of scandals that involve the destruction of political ties and market credibility

1. Scandals that involve the destruction of political ties

R1. Managers bribing government officials

R2. Managers misappropriating state assets

a. Tax evasion

b. Managers of SOEs misappropriating firm assets

c. Managers of non-SOEs misappropriating firm assets in which the government has a minority stake

2. Scandals that involve the destruction of market credibility

M1. Financial misrepresentation

M2. Managers misappropriating firm assets

a. Managers of non-SOEs misappropriating firm assets in which the government has no ownership

b. Managers of SOEs misappropriating firm assets

c. Managers of non-SOEs misappropriating firm assets in which the government has a minority stake

Panel B: Classification of scandals for our sample firms

\begin{tabular}{|c|c|c|}
\hline \multirow{2}{*}{$\begin{array}{l}\text { Category } \\
\text { Political scandals }\end{array}$} & Description & $\mathbf{N}$ \\
\hline & $\begin{array}{l}\text { Scandals that are primarily associated with the destruction of political ties } \\
\text { 1. Managers bribing government officials [R1] } \\
\text {-Bribing CSRC officials for IPOs, SEOs, and relationship building } \\
\text {-Bribing government officials to obtain loans or projects } \\
\text { 2. Tax evasion [R2a] }\end{array}$ & $\begin{array}{r}19 \\
9 \\
3 \\
31\end{array}$ \\
\hline Mixed scandals & $\begin{array}{l}\text { Scandals that are associated with the destruction of political ties and market } \\
\text { credibility } \\
\text { 1. Managers of SOEs misappropriating firm assets [R2b=M2b] } \\
\text {-Embezzlement } \\
\text {-Taking kickbacks } \\
\text {-Others (abuse of power for private gains, forgery etc.) } \\
\text { 2. Managers of non-SOEs in which government maintains a minority stake } \\
\text { misappropriating firm assets [R2c=M2c] } \\
\text { 3. Managers bribing government officials and manipulating accounting numbers } \\
\text { to conceal the bribe [R1+M1] }\end{array}$ & $\begin{array}{l}47 \\
23 \\
21 \\
15\end{array}$ \\
\hline Market scandals & $\begin{array}{l}\text { Scandals that are primarily associated with the destruction of market credibility } \\
\text { 1. Financial misrepresentation [M1] } \\
\text {-Accounting manipulations to inflate earnings } \\
\text {-False accounting disclosure } \\
\text { 2. Managers of non-SOEs misappropriating firm assets [M2a] } \\
\text {-Tunneling } \\
\text {-Excessive related party loans and guarantee }\end{array}$ & $\begin{array}{l}23 \\
\frac{11}{98}\end{array}$ \\
\hline
\end{tabular}


TABLE 2

Sample distribution by year and industry

Panel A: Sample distribution by year

\begin{tabular}{|c|c|c|c|c|c|c|}
\hline \multirow[b]{2}{*}{ Year } & \multicolumn{2}{|c|}{ Political scandals } & \multicolumn{2}{|c|}{ Mixed scandals } & \multicolumn{2}{|c|}{ Market scandals } \\
\hline & $\mathbf{N}$ & $\%$ & $\mathbf{N}$ & $\%$ & $\mathbf{N}$ & $\%$ \\
\hline 1997 & 0 & $0.00 \%$ & 2 & $1.87 \%$ & 2 & $2.04 \%$ \\
\hline 1998 & 1 & $3.23 \%$ & 0 & $0.00 \%$ & 3 & $3.06 \%$ \\
\hline 1999 & 2 & $6.45 \%$ & 7 & $6.54 \%$ & 6 & $6.12 \%$ \\
\hline 2000 & 1 & $3.23 \%$ & 10 & $9.35 \%$ & 9 & $9.18 \%$ \\
\hline 2001 & 10 & $32.26 \%$ & 9 & $8.41 \%$ & 10 & $10.20 \%$ \\
\hline 2002 & 3 & $9.68 \%$ & 12 & $11.21 \%$ & 23 & $23.47 \%$ \\
\hline 2003 & 3 & $9.68 \%$ & 16 & $14.95 \%$ & 16 & $16.33 \%$ \\
\hline 2004 & 5 & $16.13 \%$ & 17 & $15.89 \%$ & 12 & $12.24 \%$ \\
\hline 2005 & 6 & $19.35 \%$ & 34 & $31.78 \%$ & 17 & $17.35 \%$ \\
\hline Total & 31 & $100.00 \%$ & 107 & $100.00 \%$ & 98 & $100.00 \%$ \\
\hline
\end{tabular}

Panel B: Sample distribution by industry ${ }^{\mathrm{a}}$

\begin{tabular}{llcccccc}
\hline & & \multicolumn{2}{c}{ Political scandals } & \multicolumn{2}{c}{ Mixed scandals } & \multicolumn{2}{c}{ Market scandals } \\
\cline { 2 - 7 } Industry & $\mathbf{N}$ & $\mathbf{\%}$ & $\mathbf{N}$ & $\mathbf{\%}$ & $\mathbf{N}$ & $\mathbf{\%}$ \\
\hline 1 & Agriculture & 2 & $6.45 \%$ & 3 & $2.80 \%$ & 7 & $7.14 \%$ \\
2 & Natural resources & 0 & $0.00 \%$ & 1 & $0.93 \%$ & 1 & $1.02 \%$ \\
3 & Manufacturing & 16 & $51.61 \%$ & 56 & $52.34 \%$ & 47 & $47.96 \%$ \\
4 & Utilities & 1 & $3.23 \%$ & 8 & $7.48 \%$ & 0 & $0.00 \%$ \\
5 & Construction & 2 & $6.45 \%$ & 3 & $2.80 \%$ & 1 & $1.02 \%$ \\
6 & Transportation & 0 & $0.00 \%$ & 8 & $7.48 \%$ & 4 & $4.08 \%$ \\
7 & Information technology & 3 & $9.68 \%$ & 5 & $4.67 \%$ & 6 & $6.12 \%$ \\
8 & Wholesale and retail & 2 & $6.45 \%$ & 5 & $4.67 \%$ & 5 & $5.10 \%$ \\
9 & Finance and insurance & 0 & $0.00 \%$ & 1 & $0.93 \%$ & 0 & $0.00 \%$ \\
10 & Real estate & 1 & $3.23 \%$ & 4 & $3.74 \%$ & 5 & $5.10 \%$ \\
11 & Services & 1 & $3.23 \%$ & 5 & $4.67 \%$ & 5 & $5.10 \%$ \\
12 & Communication & 0 & $0.00 \%$ & 1 & $0.93 \%$ & 3 & $3.06 \%$ \\
13 & Others & 3 & $9.68 \%$ & 7 & $6.54 \%$ & 14 & $14.29 \%$ \\
& & & & & & & \\
& Total & 31 & $100.00 \%$ & 107 & $100.00 \%$ & 98 & $100.00 \%$ \\
\hline
\end{tabular}

${ }^{\mathrm{a}}$ Based on the industry classification by the CSRC. 
TABLE 3

Mean CARs/CSARs during various event windows

\begin{tabular}{|c|c|c|c|c|c|}
\hline Event window & $\begin{array}{c}\text { Political scandals } \\
\text { (1) }\end{array}$ & $\begin{array}{c}\text { Mixed scandals } \\
\text { (2) } \\
\end{array}$ & $\begin{array}{c}\text { Market scandals } \\
\text { (3) } \\
\end{array}$ & $\begin{array}{c}\text { Difference } \\
\text { (political scandal- } \\
\text { market scandal) }\end{array}$ & $\begin{array}{c}\text { Difference } \\
\text { (Mixed scandal- } \\
\text { market scandal) }\end{array}$ \\
\hline CAR $(-1,1)$ month & $\begin{array}{l}-0.152 \\
{[-3.50]^{* * *}}\end{array}$ & $\begin{array}{l}-0.143 \\
{[-6.29]^{* * *}}\end{array}$ & $\begin{array}{l}-0.046 \\
{[-3.38]^{* * *}}\end{array}$ & $\begin{array}{l}-0.106 \\
{[-3.09]^{* * *}}\end{array}$ & $\begin{array}{l}-0.097 \\
{[-3.59]^{* * *}}\end{array}$ \\
\hline CAR $(-2,2)$ months & $\begin{array}{l}-0.161 \\
{[-3.57]^{* * *}}\end{array}$ & $\begin{array}{l}-0.174 \\
{[-6.44]^{* * *}}\end{array}$ & $\begin{array}{l}-0.041 \\
{[-2.33]^{* *}}\end{array}$ & $\begin{array}{c}-0.120 \\
{[-3.02]^{* * *}}\end{array}$ & $\begin{array}{l}-0.133 \\
{[-4.07]^{* * *}}\end{array}$ \\
\hline $\operatorname{CSAR}(-6,6)$ months & $\begin{array}{l}-0.298 \\
{[-3.74]^{* * *}}\end{array}$ & $\begin{array}{l}-0.203 \\
{[-6.75]^{* * *}}\end{array}$ & $\begin{array}{l}-0.083 \\
{[-3.91]^{* * *}}\end{array}$ & $\begin{array}{l}-0.216 \\
{[-3.71]^{* * *}}\end{array}$ & $\begin{array}{l}-0.120 \\
{[-3.22]^{* * *}}\end{array}$ \\
\hline CSAR $(-12,12)$ months & $\begin{array}{l}-0.399 \\
{[-3.76]^{* * *}} \\
31\end{array}$ & $\begin{array}{c}-0.243 \\
{[-6.02]^{* * *}} \\
107\end{array}$ & $\begin{array}{l}-0.132 \\
{[-3.45]^{* * *}} \\
98\end{array}$ & $\begin{array}{l}-0.268 \\
{[-2.97]^{* * *}}\end{array}$ & $\begin{array}{l}-0.111 \\
{[-1.99]^{*}}\end{array}$ \\
\hline
\end{tabular}


TABLE 4

Regression analysis of market reactions

Panel A: Descriptive statistics $(\mathrm{N}=236)$

\begin{tabular}{|c|c|c|c|}
\hline Variables & $\begin{array}{c}\text { Political scandal } \\
(\mathrm{N}=\mathbf{3 1})\end{array}$ & $\begin{array}{l}\text { Mixed scandal } \\
\quad(\mathrm{N}=107)\end{array}$ & $\begin{array}{l}\text { Market scandal } \\
(\mathrm{N}=98)\end{array}$ \\
\hline \multicolumn{4}{|l|}{ Magnitude of scandal (\%) } \\
\hline Mean & 12.551 & 4.552 & 14.992 \\
\hline Median & 0.006 & 0.105 & 3.878 \\
\hline Std. dev. & 52.741 & 17.713 & 29.966 \\
\hline \multicolumn{4}{|l|}{ Stock return $_{\text {pre }}$} \\
\hline Mean & 0.143 & 0.032 & 0.065 \\
\hline Median & 0.083 & -0.014 & 0.083 \\
\hline Std. dev. & 0.333 & 0.310 & 0.286 \\
\hline \multicolumn{4}{|l|}{$\mathbf{R O A}_{\text {pre }}$} \\
\hline Mean & 0.033 & 0.007 & -0.012 \\
\hline Median & 0.031 & 0.020 & 0.004 \\
\hline Std. dev. & 0.078 & 0.073 & 0.077 \\
\hline \multicolumn{4}{|l|}{ Firm size $_{\text {pre }}$} \\
\hline Mean & 21.069 & 21.055 & 20.636 \\
\hline Median & 20.969 & 20.864 & 20.643 \\
\hline Std. dev. & 0.791 & 0.935 & 0.784 \\
\hline \multicolumn{4}{|l|}{ Market-to-book $_{\text {pre }}$} \\
\hline Mean & 3.238 & 2.613 & 3.111 \\
\hline Median & 3.094 & 2.122 & 2.893 \\
\hline Std. dev. & 1.695 & 1.307 & 1.354 \\
\hline \multicolumn{4}{|l|}{ Tangibility $_{\text {pre }}$} \\
\hline Mean & 0.298 & 0.430 & 0.346 \\
\hline Median & 0.256 & 0.402 & 0.326 \\
\hline Std. dev. & 0.179 & 0.258 & 0.182 \\
\hline \multicolumn{4}{|l|}{ SOE } \\
\hline Mean & 0.677 & 0.850 & 0.816 \\
\hline Median & 1.000 & 1.000 & 1.000 \\
\hline Std. dev. & 0.475 & 0.358 & 0.389 \\
\hline \multicolumn{4}{|l|}{ Legal environment } \\
\hline Mean & 5.785 & 5.851 & 5.681 \\
\hline Median & 6.457 & 5.418 & 5.468 \\
\hline Std. dev. & 1.983 & 1.848 & 1.865 \\
\hline \multicolumn{4}{|l|}{ Legal penalties imposed on firms } \\
\hline \multicolumn{4}{|l|}{ Monetary penalty (in US\$ million) } \\
\hline Mean & 88.680 & 4.562 & 0.071 \\
\hline Median & 0.158 & 0.061 & 0.048 \\
\hline Std. dev. & 211.892 & 13.291 & 0.133 \\
\hline \multicolumn{4}{|l|}{ Non-monetary penalty } \\
\hline Criticism, rectification and suspension & 8 & 26 & 53 \\
\hline \multicolumn{4}{|l|}{ Legal Penalties imposed on individuals } \\
\hline \multicolumn{4}{|l|}{ Monetary penalty (in US\$ million) } \\
\hline Mean & 0.114 & 0.452 & 0.033 \\
\hline Median & 0.030 & 0.049 & 0.028 \\
\hline Std. dev. & 0.154 & 1.093 & 0.025 \\
\hline \multicolumn{4}{|l|}{ Non-monetary penalty } \\
\hline Criticism and bar from securities market & 10 & 23 & 69 \\
\hline Imprisonment and death penalty & 14 & 67 & 1 \\
\hline $\begin{array}{l}\text { Others (pending investigation, secret hearing, } \\
\text { fled the country) }\end{array}$ & 7 & 29 & 0 \\
\hline
\end{tabular}


TABLE 4, continued

Panel B: Regression of CARs/CSARs on types of scandals, control variables, and legal penalties ${ }^{\text {a }}$

\begin{tabular}{|c|c|c|c|c|c|c|c|c|}
\hline & $\begin{array}{c}\text { CAR } \\
(-1,1) \\
\text { month } \\
\end{array}$ & $\begin{array}{c}\text { CAR } \\
(-2,2) \\
\text { months }\end{array}$ & $\begin{array}{c}\text { CSAR } \\
(-6,6) \\
\text { months } \\
\end{array}$ & $\begin{array}{c}\text { CSAR } \\
(-12,12) \\
\text { months }\end{array}$ & $\begin{array}{c}\text { CAR } \\
(-1,1) \\
\text { month } \\
\end{array}$ & $\begin{array}{c}\text { CAR } \\
(-2,2) \\
\text { months }\end{array}$ & $\begin{array}{c}\text { CSAR } \\
(-6,6) \\
\text { months }\end{array}$ & $\begin{array}{c}\text { CSAR } \\
(-12,12) \\
\text { months }\end{array}$ \\
\hline & (1) & $(2)$ & (3) & $(4)$ & (5) & $(6)$ & (7) & (8) \\
\hline Political scandal & {$[-1.75]^{*}$} & {$[-1.94]^{*}$} & {$[-2.96] * * *$} & {$[-3.22] * * *$} & {$[-1.92]^{*}$} & {$[-2.17] * *$} & {$[-2.63]^{* * * *}$} & {$[-2.36]^{* *}$} \\
\hline \multirow[t]{2}{*}{ Mixed scandal } & -0.123 & -0.164 & -0.172 & -0.211 & -0.145 & -0.192 & -0.218 & -0.220 \\
\hline & {$[-4.32] * * *$} & {$[-4.86]^{* * *}$} & {$[-4.25] * * *$} & {$[-3.64] * * *$} & {$[-3.85] * * *$} & {$[-4.33]^{* * *}$} & {$[-3.73]^{* * *}$} & {$[-2.59] * *$} \\
\hline \multicolumn{9}{|l|}{ Control variables } \\
\hline \multirow[t]{2}{*}{ Magnitude of scandal } & 0.000 & 0.001 & 0.000 & 0.000 & 0.001 & 0.001 & 0.001 & 0.001 \\
\hline & {$[0.77]$} & {$[0.98]$} & {$[0.36]$} & {$[0.22]$} & [1.44] & {$[1.61]$} & {$[1.60]$} & [0.93] \\
\hline \multirow[t]{2}{*}{ Stock return $_{\text {pre }}$} & 0.006 & -0.023 & -0.077 & 0.006 & 0.015 & -0.011 & 0.102 & 0.359 \\
\hline & {$[0.12]$} & {$[-0.37]$} & {$[-1.05]$} & {$[0.06]$} & [0.29] & {$[-0.18]$} & {$[1.31]$} & {$[3.17] * * *$} \\
\hline \multirow[t]{2}{*}{$\mathrm{ROA}_{\text {pre }}$} & 0.196 & 0.303 & 1.055 & 1.882 & 0.145 & 0.244 & 1.050 & 1.812 \\
\hline & {$[1.01]$} & {$[1.31]$} & {$[3.83]^{* * *}$} & {$[4.77]^{* * *}$} & {$[0.76]$} & {$[1.08]$} & {$[3.52] * * *$} & {$[4.19]^{* * *}$} \\
\hline \multirow[t]{2}{*}{ Firm size $_{\text {pre }}$} & -0.040 & -0.035 & -0.115 & -0.167 & -0.022 & -0.012 & -0.038 & -0.015 \\
\hline & {$[-2.11]^{* *}$} & {$[-1.56]$} & {$[-4.24] * * *$} & {$[-4.32] * * *$} & {$[-1.12]$} & {$[-0.53]$} & {$[-1.25]$} & {$[-0.34]$} \\
\hline \multirow[t]{2}{*}{ Tangibility pre } & 0.087 & 0.065 & 0.175 & 0.176 & 0.023 & -0.015 & -0.018 & -0.038 \\
\hline & {$[1.28]$} & {$[0.81]$} & {$[1.82]^{*}$} & {$[1.28]$} & {$[0.33]$} & {$[-0.19]$} & {$[-0.17]$} & {$[-0.25]$} \\
\hline \multirow[t]{2}{*}{ SOE } & 0.124 & 0.133 & 0.112 & 0.045 & 0.107 & 0.112 & 0.098 & 0.038 \\
\hline & {$[3.54] * * *$} & {$[3.21] * * *$} & {$[2.25]^{* *}$} & {$[0.64]$} & {$[3.11] * * *$} & {$[2.75]^{* * *}$} & {$[1.83]^{*}$} & [0.49] \\
\hline \multirow[t]{2}{*}{ Legal environment } & 0.008 & 0.008 & 0.007 & 0.019 & 0.001 & -0.001 & -0.010 & 0.004 \\
\hline & {$[1.14]$} & {$[0.94]$} & {$[0.70]$} & {$[1.30]$} & {$[0.18]$} & {$[-0.11]$} & {$[-0.88]$} & {$[0.22]$} \\
\hline \multicolumn{9}{|l|}{ Penalty on firms } \\
\hline \multirow[t]{2}{*}{ Monetary penalty } & & & & & -0.780 & -0.927 & -1.410 & -0.763 \\
\hline & & & & & {$[-2.98] * * *$} & {$[-3.01] * * *$} & {$[-3.47] * * *$} & {$[-1.29]$} \\
\hline \multirow[t]{2}{*}{ Criticism, rectification and suspension } & & & & & -0.054 & -0.078 & -0.036 & -0.070 \\
\hline & & & & & {$[-1.89]^{*}$} & {$[-2.32] * *$} & {$[-0.82]$} & {$[-1.09]$} \\
\hline \multicolumn{9}{|l|}{ Penalty on individuals } \\
\hline \multirow[t]{2}{*}{ Monetary penalty } & & & & & 36.543 & 51.749 & 32.325 & 29.038 \\
\hline & & & & & {$[1.72]^{*}$} & {$[2.07] * *$} & {$[0.98]$} & {$[0.61]$} \\
\hline \multirow[t]{2}{*}{ Criticism and bar from securities market } & & & & & -0.058 & -0.068 & -0.118 & -0.033 \\
\hline & & & & & {$[-1.95]^{*}$} & {$[-1.94]^{*}$} & {$[-2.55]^{* *}$} & {$[-0.49]$} \\
\hline Industry dummy & Included & Included & Included & Included & Included & Included & Included & Included \\
\hline $\mathrm{N}$ & 236 & 236 & 236 & 236 & 236 & 236 & 236 & 236 \\
\hline Adj. $\mathrm{R}^{2}$ & 0.138 & 0.139 & 0.209 & 0.221 & 0.185 & 0.196 & 0.240 & 0.222 \\
\hline
\end{tabular}

$\mathrm{a}_{*}, * *, * * *$ indicate significance at the $0.10,0.05$, and 0.01 levels (two-tailed), respectively. $t$-statistics in brackets.

Variable definitions: See Appendix 2. 
TABLE 5

Analysis examining the role of political dependence

Panel A: Descriptive statistics on conditional variables $(\mathbf{N}=\mathbf{2 3 6})$

\begin{tabular}{lccccc}
\hline Variables & Mean & Q1 & Median & Q3 & Std. dev. \\
\hline Weak provincial development & 0.491 & 0.000 & 0.000 & 1.000 & 0.501 \\
Strong political connectedness & 0.593 & 0.000 & 1.000 & 1.000 & 0.492 \\
\hline
\end{tabular}

Panel B: Regression of CARs/CSARs on types of scandals and control variables, conditional on provincial development ${ }^{\text {a }}$

\begin{tabular}{|c|c|c|c|c|}
\hline & $\begin{array}{c}\text { CAR } \\
(-1,1) \text { month } \\
\end{array}$ & $\begin{array}{c}\text { CAR } \\
(-2,2) \text { months } \\
\end{array}$ & $\begin{array}{c}\text { CSAR } \\
(-6,6) \text { months } \\
\end{array}$ & $\begin{array}{c}\text { CSAR } \\
(-12,12) \text { months }\end{array}$ \\
\hline & $(\mathbf{1})$ & $(2)$ & (3) & $(4)$ \\
\hline \multirow[t]{2}{*}{ Political scandal $\left(\beta_{l}\right)$} & 0.029 & 0.000 & 0.013 & -0.186 \\
\hline & {$[0.51]$} & {$[0.01]$} & {$[0.16]$} & {$[-1.57]$} \\
\hline \multirow[t]{2}{*}{ Mixed scandal $\left(\beta_{2}\right)$} & -0.040 & -0.097 & -0.092 & -0.176 \\
\hline & {$[-0.99]$} & {$[-2.03]^{* *}$} & {$[-1.62]$} & {$[-2.10]^{* *}$} \\
\hline \multirow{2}{*}{ Weak provincial development $\left(\beta_{3}\right)$} & 0.013 & -0.002 & 0.098 & 0.111 \\
\hline & {$[0.30]$} & {$[-0.04]$} & {$[1.55]$} & {$[1.20]$} \\
\hline \multirow[t]{2}{*}{ Political scandal $\times$ Weak provincial develop. $\left(\beta_{4}\right)$} & -0.203 & -0.196 & -0.390 & -0.179 \\
\hline & {$[-2.44]^{* *}$} & {$[-1.96]^{*}$} & {$[-3.28] * * *$} & {$[-1.03]$} \\
\hline \multirow[t]{2}{*}{ Mixed scandal $\times$ Weak provincial develop. $\left(\beta_{5}\right)$} & -0.158 & -0.127 & -0.159 & -0.071 \\
\hline & {$[-2.91]^{* * *}$} & {$[-1.94] *$} & {$[-2.03]^{* *}$} & {$[-\mathbf{0 . 6 3}]$} \\
\hline Control variables & Included & Included & Included & Included \\
\hline Industry dummy & Included & Included & Included & Included \\
\hline $\mathrm{N}$ & 236 & 236 & 236 & 236 \\
\hline Adj. $\mathrm{R}^{2}$ & 0.189 & 0.164 & 0.240 & 0.216 \\
\hline \multicolumn{5}{|l|}{ Diff. political-market scandals, strong provincial } \\
\hline devlop. $\left(\beta_{1}\right)$ & 0.029 & 0.000 & 0.013 & -0.186 \\
\hline \multicolumn{5}{|l|}{ Diff. political-market scandals, weak provincial } \\
\hline devlop. $\left(\beta_{1}+\beta_{4}\right)$ & $-0.174 * * *$ & $-0.196 * * *$ & $-0.377 * * *$ & $-0.365 * * *$ \\
\hline \multicolumn{5}{|l|}{ Diff. mixed-market scandals, strong provincial } \\
\hline devlop. $\left(\beta_{2}\right)$ & -0.040 & $-0.097 * *$ & -0.092 & $-0.176 * *$ \\
\hline \multicolumn{5}{|l|}{ Diff. mixed-market scandals, weak provincial } \\
\hline devlop. $\left(\beta_{2}+\beta_{5}\right)$ & $-0.198 * * *$ & $-0.224 * * *$ & $-0.251 * * *$ & $-0.247 * * *$ \\
\hline
\end{tabular}


TABLE 5, continued

Panel C: Regression of CARs/CSARs on types of scandals and control variables, conditional on firm-level political connectedness $^{\mathrm{a}}$

\begin{tabular}{|c|c|c|c|c|}
\hline & $\begin{array}{c}\text { CAR } \\
(-1,1) \text { month } \\
\end{array}$ & $\begin{array}{c}\text { CAR } \\
(-2,2) \text { months }\end{array}$ & $\begin{array}{c}\text { CSAR } \\
(-6,6) \text { months }\end{array}$ & $\begin{array}{c}\text { CSAR } \\
(-12,12) \text { months }\end{array}$ \\
\hline & (1) & $(2)$ & (3) & (4) \\
\hline Political scandal $\left(\beta_{1}\right)$ & $\begin{array}{r}0.025 \\
{[0.41]}\end{array}$ & $\begin{array}{l}-0.019 \\
{[-0.26]}\end{array}$ & $\begin{array}{c}0.008 \\
{[0.09]}\end{array}$ & $\begin{array}{c}0.034 \\
{[0.26]}\end{array}$ \\
\hline Mixed scandal $\left(\beta_{2}\right)$ & $\begin{array}{r}0.003 \\
{[0.07]}\end{array}$ & $\begin{array}{l}-0.034 \\
{[-0.68]}\end{array}$ & $\begin{array}{l}-0.062 \\
{[-1.02]}\end{array}$ & $\begin{array}{l}-0.125 \\
{[-1.43]}\end{array}$ \\
\hline Strong political connectedness $\left(\beta_{3}\right)$ & $\begin{array}{c}0.043 \\
{[1.10]}\end{array}$ & $\begin{array}{l}0.030 \\
{[0.64]}\end{array}$ & $\begin{array}{l}0.019 \\
{[0.34]}\end{array}$ & $\begin{array}{l}0.051 \\
{[0.63]}\end{array}$ \\
\hline Political scandal $\times$ Strong political connect. $\left(\beta_{4}\right)$ & $\begin{array}{c}-0.155 \\
{[-1.90]^{*}}\end{array}$ & $\begin{array}{l}-0.116 \\
{[-1.18]}\end{array}$ & $\begin{array}{l}-0.293 \\
{[-2.49]^{* *}}\end{array}$ & $\begin{array}{l}-0.509 \\
{[-3.00]^{*} * *}\end{array}$ \\
\hline Mixed scandal $\times$ Strong political connect. $\left(\beta_{5}\right)$ & $\begin{array}{l}-\mathbf{0 . 1 9 7} \\
{[-3.67] * * *}\end{array}$ & $\begin{array}{l}-0.200 \\
{[-3.11]^{* * * *}}\end{array}$ & $\begin{array}{l}-0.168 \\
{[-2.18]^{* *}}\end{array}$ & $\begin{array}{l}-0.138 \\
{[-1.24]}\end{array}$ \\
\hline Control variables & Included & Included & Included & Included \\
\hline Industry dummy & Included & Included & Included & Included \\
\hline $\mathrm{N}$ & 236 & 236 & 236 & 236 \\
\hline Adj. $\mathrm{R}^{2}$ & 0.202 & 0.186 & 0.249 & 0.249 \\
\hline $\begin{array}{l}\text { Diff. political-market scandals, weak political } \\
\text { connect. }\left(\beta_{1}\right) \\
\text { Diff. political-market scandals, strong political }\end{array}$ & 0.025 & -0.019 & 0.008 & 0.034 \\
\hline connect. $\left(\beta_{1}+\beta_{4}\right)$ & $-0.130 * * *$ & $-0.135 * *$ & $-0.285 * * *$ & $-0.475 * * *$ \\
\hline $\begin{array}{l}\text { Diff. mixed-market scandals, weak political } \\
\text { connect. }\left(\beta_{2}\right) \\
\text { Diff. mixed-market scandals, strong political }\end{array}$ & 0.003 & -0.034 & -0.062 & -0.125 \\
\hline connect. $\left(\beta_{2}+\beta_{5}\right)$ & $-0.194 * * *$ & $-0.234 * * *$ & $-0.230 * * *$ & $-0.263 * * *$ \\
\hline
\end{tabular}


TABLE 6

Impact of scandals on operating performance

Panel A: Descriptive statistics on additional variables

\begin{tabular}{lcccccc}
\hline Variables & N & Mean & Q1 & Median & Q3 & Std. dev. \\
\hline$\Delta$ ROA & 212 & -0.049 & -0.091 & -0.021 & 0.014 & 0.101 \\
$\Delta$ Sales growth & 212 & -0.023 & -0.078 & -0.007 & 0.067 & 0.171 \\
\hline
\end{tabular}

Panel B: Regressions with the dependent variable being changes in operating performance and sales growth

\begin{tabular}{lcc}
\hline & $\boldsymbol{\Delta}$ ROA & $\Delta$ Sales Growth \\
\hline Political scandal & $\mathbf{- 0 . 0 6 4}$ & $\mathbf{- 0 . 0 7 4}$ \\
Mixed scandal & {$[\mathbf{- 3 . 0 6}]^{* * *}$} & {$[\mathbf{- 1 . 8 4}]^{*}$} \\
& $-\mathbf{0 . 0 4 0}$ & $\mathbf{- 0 . 0 7 3}$ \\
Magnitude of scandal & {$[-\mathbf{2 . 8 3}]^{* * *}$} & {$[-\mathbf{- 2 . 7 3}]^{* * *}$} \\
& -0.000 & -0.000 \\
Stock return & {$[-2.12]^{* *}$} & 0.074 \\
& 0.035 & {$[1.82]^{*}$} \\
ROA $_{\text {pre }}$ & {$[1.65]$} & -0.451 \\
& -0.498 & {$[-2.17]^{* *}$} \\
Firm size & {$[-4.57]^{* * *}$} & -0.000 \\
& 0.008 & {$[-0.02]$} \\
Market-to-book $_{\text {pre }}$ & {$[0.89]$} & -0.008 \\
& 0.006 & {$[-0.66]$} \\
Tangibility & {$[1.02]$} & -0.025 \\
& 0.008 & {$[-0.39]$} \\
SOE & {$[0.25]$} & 0.059 \\
& 0.055 & {$[1.91]^{*}$} \\
Legal environment & {$[3.41]^{* * *}$} & -0.011 \\
& 0.004 & {$[-1.63]$} \\
Industry dummy & {$[1.24]$} & Included \\
$\mathrm{N}$ & Included & 212 \\
Adj. $\mathrm{R}^{2}$ & 212 & 0.057 \\
\hline
\end{tabular}

$\mathrm{a} *, * *, * * *$ indicate significance at the $0.10,0.05$, and 0.01 levels (two-tailed), respectively. $t$-statistics in brackets.

Variable definitions: See Appendix 2. 
TABLE 7

Impact of scandals on financing

Panel A: Descriptive statistics on additional variables

\begin{tabular}{lcccccc}
\hline Variables & N & Mean & Q1 & Median & Q3 & Std. dev. \\
\hline$\Delta$ Loans from SB & 171 & 0.036 & -0.046 & 0.013 & 0.098 & 0.132 \\
$\Delta$ (Loans from SB + government) & 171 & 0.037 & -0.046 & 0.010 & 0.109 & 0.133 \\
$\Delta$ Overdue borrowing from SB & 212 & 0.258 & 0.000 & 0.000 & 0.500 & 0.540 \\
$\Delta$ Total debt & 212 & 0.036 & -0.027 & 0.026 & 0.109 & 0.107 \\
$\Delta$ Firm size & 212 & -0.044 & -0.354 & -0.021 & 0.298 & 0.549 \\
$\Delta$ Market-to-book & 212 & -0.736 & -1.361 & -0.538 & -0.069 & 1.252 \\
$\Delta$ Tangibility & 212 & 0.108 & 0.024 & 0.076 & 0.173 & 0.167 \\
\hline
\end{tabular}

Panel B: Regressions with the dependent variable being changes in financing ${ }^{\mathrm{a}}$

\begin{tabular}{lcccc}
\hline & $\boldsymbol{\Delta}$ Loans from SB & $\begin{array}{c}\Delta \text { (Loans from SB } \\
\text { government) }\end{array}$ & $\begin{array}{c}\Delta \text { Overdue } \\
\text { borrowings from SB }\end{array}$ & $\boldsymbol{\Delta}$ Total debt \\
\hline Political scandal & $\mathbf{- 0 . 0 8 1}$ & $\mathbf{- 0 . 0 7 9}$ & $\mathbf{0 . 3 3 7}$ & $\mathbf{- 0 . 0 1 2}$ \\
& {$[-\mathbf{2 . 3 5}]^{* *}$} & {$[-\mathbf{2 . 2 3}]^{* *}$} & {$[\mathbf{2 . 7 2}]^{* * *}$} & {$[-\mathbf{0 . 4 6}]$} \\
Mixed scandal & $\mathbf{- 0 . 0 4 1}$ & $\mathbf{- 0 . 0 4 2}$ & $\mathbf{0 . 0 9 4}$ & $\mathbf{- 0 . 0 0 4}$ \\
& {$[-\mathbf{1 . 8 8}]^{*}$} & {$[-\mathbf{1 . 8 6}]^{*}$} & {$[\mathbf{1 . 1 5}]$} & {$[-\mathbf{0 . 2 3}]$} \\
Magnitude of scandal & 0.000 & 0.000 & 0.000 & 0.000 \\
& {$[1.04]$} & {$[0.96]$} & {$[0.57]$} & {$[0.24]$} \\
$\Delta$ ROA & -0.550 & -0.551 & -1.098 & -0.366 \\
& {$[-4.96]^{* * *}$} & {$[-4.84]^{* * *}$} & {$[-2.61]^{* * *}$} & {$[-4.23]^{* * *}$} \\
$\Delta$ Firm size & -0.041 & -0.041 & -0.145 & 0.024 \\
& {$[-1.70]^{*}$} & {$[-1.64]$} & {$[-1.67]^{*}$} & {$[1.32]$} \\
$\Delta$ Market-to-book & -0.014 & -0.015 & -0.007 & -0.004 \\
& {$[-1.62]$} & {$[-1.74]^{*}$} & {$[-0.19]$} & {$[-0.55]$} \\
$\Delta$ Tangibility & 0.113 & 0.099 & 0.293 & 0.083 \\
& {$[1.65]$} & {$[1.41]$} & {$[1.14]$} & {$[1.57]$} \\
SOE & 0.022 & 0.023 & -0.043 & 0.018 \\
& {$[0.90]$} & {$[0.92]$} & {$[-0.46]$} & {$[0.95]$} \\
Legal environment & -0.002 & -0.002 & -0.036 & -0.008 \\
& {$[-0.30]$} & {$[-0.32]$} & {$[-1.72]^{*}$} & {$[-1.85]^{*}$} \\
Industry dummy & Included & Included & Included & Included \\
Year dummy & Included & Included & Included & Included \\
N & 171 & 171 & 212 & 212 \\
Adj. $\mathrm{R}^{2}$ & 0.227 & 0.207 & 0.192 & 0.117 \\
\hline
\end{tabular}

a*, **, *** indicate significance at the $0.10,0.05$, and 0.01 levels (two-tailed), respectively. $t$-statistics in brackets.

Variable definitions: See Appendix 2. 
TABLE 8

Impact of scandals on governance

Panel A: Descriptive statistics on additional variables $(\mathrm{N}=212)$

\begin{tabular}{lccccc}
\hline Variables & Mean & Q1 & Median & Q3 & Std. dev. \\
\hline Departure of political directors & 0.145 & 0.000 & 0.091 & 0.200 & 0.175 \\
Entrance of political directors & 0.105 & 0.000 & 0.077 & 0.167 & 0.124 \\
Net gain of political directors & 0.384 & 0.000 & 0.000 & 1.000 & 0.487 \\
\hline
\end{tabular}

Panel B: Regressions for the realignment of political directors and the long-term market return effect ${ }^{\text {a }}$

\begin{tabular}{|c|c|c|c|c|}
\hline & $\begin{array}{c}\text { Departure of } \\
\text { political directors }\end{array}$ & $\begin{array}{c}\text { Entrance of } \\
\text { political directors }\end{array}$ & & $\begin{array}{c}\text { CSAR } \\
(-1,36) \text { months }\end{array}$ \\
\hline & (1) & (2) & & (3) \\
\hline Political scandal & $\begin{array}{l}\mathbf{0 . 0 7 8} \\
{[2.01]^{*} * *}\end{array}$ & $\begin{array}{l}\mathbf{0 . 1 0 0} \\
{[3.33]^{*} * *}\end{array}$ & Political scandal & $\begin{array}{l}-0.136 \\
{[-2.88]^{* * *}}\end{array}$ \\
\hline Mixed scandal & $\begin{array}{l}0.137 \\
{[5.41]^{* * *}}\end{array}$ & $\begin{array}{l}0.065 \\
{[3.26]^{* * * *}}\end{array}$ & Mixed scandal & $\begin{array}{l}-0.076 \\
{[-2.72]^{* * *}}\end{array}$ \\
\hline Magnitude of scandal & $\begin{array}{l}0.000 \\
{[1.27]}\end{array}$ & $\begin{array}{l}0.000 \\
{[0.34]}\end{array}$ & Net gain of political directors & $\begin{array}{l}0.060 \\
{[1.97]^{*}}\end{array}$ \\
\hline$\triangle \mathrm{ROA}$ & $\begin{array}{l}-0.076 \\
{[-0.58]}\end{array}$ & $\begin{array}{l}-0.047 \\
{[-0.45]}\end{array}$ & $\begin{array}{l}\text { Political scandal*Net gain of } \\
\text { political directors }\end{array}$ & $\begin{array}{c}0.124 \\
{[1.87]^{*}}\end{array}$ \\
\hline$\Delta$ Firm size & $\begin{array}{l}-0.016 \\
{[-0.60]}\end{array}$ & $\begin{array}{l}-0.034 \\
{[-1.62]}\end{array}$ & $\begin{array}{l}\text { Mixed scandal* Net gain of } \\
\text { political directors }\end{array}$ & $\begin{array}{l}0.008 \\
{[0.17]}\end{array}$ \\
\hline$\Delta$ Market-to-book & $\begin{array}{l}-0.005 \\
{[-0.49]}\end{array}$ & $\begin{array}{l}-0.007 \\
{[-0.83]}\end{array}$ & $\begin{array}{l}\text { Other control variables } \\
\mathrm{N}\end{array}$ & $\begin{array}{l}\text { Included } \\
212\end{array}$ \\
\hline$\Delta$ Tangibility & $\begin{array}{l}0.045 \\
{[0.56]}\end{array}$ & $\begin{array}{l}-0.015 \\
{[-0.24]}\end{array}$ & Adj. $R^{2}$ & 0.227 \\
\hline SOE & $\begin{array}{l}-0.042 \\
{[-1.44]}\end{array}$ & $\begin{array}{l}0.010 \\
{[0.46]}\end{array}$ & & \\
\hline Legal environment & $\begin{array}{l}0.009 \\
{[1.41]}\end{array}$ & $\begin{array}{l}0.002 \\
{[0.31]}\end{array}$ & & \\
\hline Industry dummy & Included & Included & & \\
\hline Year dummy & Included & Included & & \\
\hline $\mathrm{N}$ & 212 & 212 & & \\
\hline Adj. $R^{2}$ & 0.253 & 0.088 & & \\
\hline
\end{tabular}

a*, $* *, * * *$ indicate significance at the $0.10,0.05$, and 0.01 levels (two-tailed), respectively. $t$-statistics in brackets.

Variable definitions: See Appendix 2. 
Figure 1 Characteristics-adjusted abnormal returns (CSARs) for different types of scandals

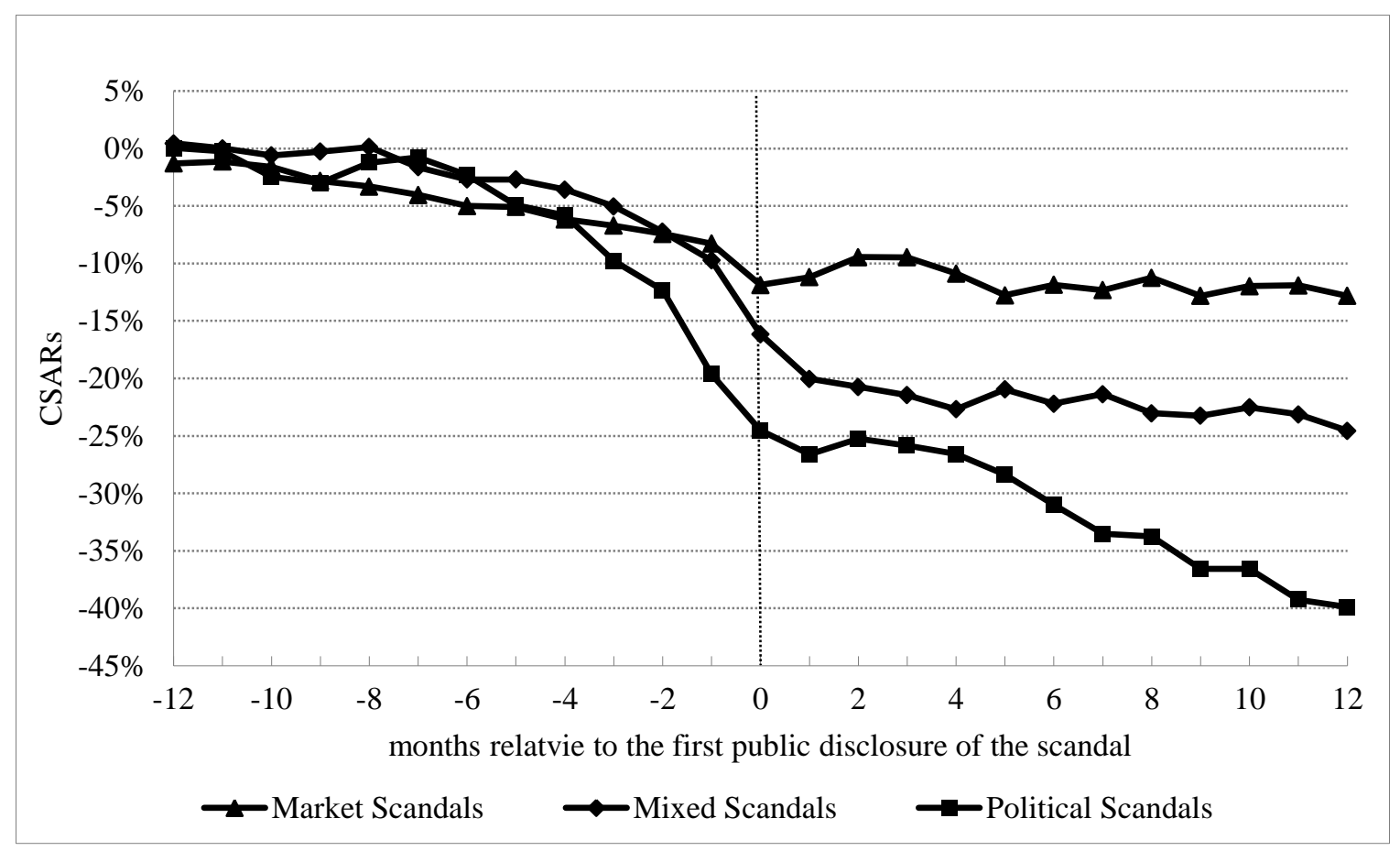

Market scandals are scandals that are primarily associated with the destruction of market credibility, including financial misrepresentation and managers of non-SOEs misappropriating firm assets.

Mixed scandals are scandals that are associated with the destruction of political ties and market credibility, including managers of SOEs misappropriating firm assets, managers of non-SOEs in which government maintains a minority stake misappropriating firm assets, and managers bribing government officials and manipulating accounting numbers to conceal the bribe.

Political scandals are scandals that are primarily associated with the destruction of political ties, including managers bribing government officials and tax evasion. 